\title{
Isotopic variation among Amazonian floodplain woody plants and implications for food-web research
}

\author{
Sandra Bibiana Correa ${ }^{1,4}$, Kirk Winemiller ${ }^{2}$ \& Dairon Cárdenas ${ }^{3}$ \\ ${ }^{1}$ University of Georgia, Department of Genetics \& Odum School of Ecology, 120 Green St., Athens, \\ GA 30601, United States. \\ ${ }^{2}$ Texas A\&M University, Department of Wildlife and Fisheries Sciences, College Station, TX, \\ United States. \\ ${ }^{3}$ Instituto Amazónico de Investigaciones Cientificas SINCHI, Bogotá, Colombia. \\ ${ }^{4}$ Corresponding author: Sandra Bibiana Correa, e-mail: sbcorrea@uga.edu
}

CORREA, S.B., WINEMILLER, K., CÁRDENAS, D. Isotopic variation among Amazonian floodplain woody plants and implications for food-web research. Biota Neotropica. 16(2): e20150078. http://dx.doi.org/10.1590/1676-0611-BN-2015-0078

\begin{abstract}
Isotopic variation within food sources adds uncertainty to models intended to reconstruct trophic pathways. Understanding this variation is pivotal for planning sampling protocols for food-web research. This study investigates natural variation in $\mathrm{C}$ and $\mathrm{N}$ stable isotopes among plant species in two western Amazon flooded forests with contrasting watershed biogeochemistry (white-water várzea-forest and black-water igapó-forest). Our objectives were to compare $\delta^{13} \mathrm{C}$ and $\delta^{15} \mathrm{~N}$ of leaves and fruits between sites; assess the magnitude of within-site variation in $\delta^{13} \mathrm{C}$ and $\delta^{15} \mathrm{~N}$ of leaves (várzea: 28 spp., igapó: $10 \mathrm{spp}$.) and fruits (várzea: $22 \mathrm{spp}$., igapó: $22 \mathrm{spp}$.); determine within-plant variation in $\delta^{13} \mathrm{C}$ and $\delta^{15} \mathrm{~N}$ of leaf, wood and fruit tissues; and test whether inter-specific variation in $\delta^{13} \mathrm{C}$ and $\delta^{15} \mathrm{~N}$ influence the results of a mixing model predicting the contribution of terrestrial $\mathrm{C}$ sources to an aquatic consumer. Mean $\delta^{13} \mathrm{C}$ values of leaves and fruits were not statistically different between the two sites despite regional differences in biogeochemistry and floristic composition. In contrast, mean $\delta^{15} \mathrm{~N}$ of leaves and fruits were significantly lower at the várzea than at the igapó site. The high floristic diversity of both forests was reflected in large within-site interspecific variation in both $\delta^{13} \mathrm{C}$ and $\delta^{15} \mathrm{~N}$. Paired comparisons revealed that $\delta^{13} \mathrm{C}$ of wood and fruits and $\delta^{15} \mathrm{~N}$ of fruits were generally greater than values obtained for leaves from the same plant. The predicted contribution of different carbon sources to the consumer biomass changed between models as a function of source variability. We discuss implications of source variation for designing sampling protocols, interpreting isotopic signatures, and establishing trophic links between plants and consumers. Our findings highlight the importance of in situ sampling to establish reliable primary production baselines for local food webs.
\end{abstract}

Keywords: Stable isotopes, Igapó, Várzea, Fruits, Food web, Mixing model.

CORREA, S.B., WINEMILLER, K., CÁRDENAS, D. Variación isotópica entre plantas leñosas de planicies de inundación del Amazonas e implicaciones para la investigación de red tróficas. Biota Neotropica. 16(2): e20150078. http://dx.doi.org/10.1590/1676-0611-BN-2015-0078

Resumo: La variación isotópica dentro de fuentes alimenticias añade incertidumbre a los modelos destinados a reconstruir redes tróficas. La comprensión de esta variación es fundamental para la planificación de protocolos de muestreo para la investigación de redes alimentarias. Este estudio investiga la variación natural en isótopos estables de $\mathrm{C}$ y $\mathrm{N}$ entre especies de plantas en dos bosques inundables de la Amazonía noroccidental con biogeoquímica de cuenca contrastantes (várzea-bosques de aguas blanca e igapó-bosques de aguas negras). Nuestros objetivos fueron comparar las señales isotópicas de $\delta^{13} \mathrm{C}$ y $\delta^{15} \mathrm{~N}$ de hojas y frutos entre bosques; evaluar la magnitud de la variación en la composición isotópica de hojas (várzea: 28 spp., Igapó: 10 spp.) y frutas (várzea:. 22 spp, igapó: 22 spp.) a nivel local; determinar la variación en la composición isotópica de madera, hojas y frutas dentro de una planta; y evaluar si la variación inter-específica en los valores de $\delta^{13} \mathrm{C}$ y $\delta^{15} \mathrm{~N}$ ejerce influencia sobre los resultados de modelos que predicen la contribución de fuentes de alimentos terrestres a un consumidor acuático. Los valores promedio de $\delta^{13} \mathrm{C}$ en hojas y frutos no fueron estadísticamente diferentes entre los dos tipos de bosque a pesar de las diferencias regionales en biogeoquímica y composición florística. Por el contrario, los valores promedio de $\delta^{15} \mathrm{~N}$ en hojas y frutos fueron significativamente más bajos en la várzea que en el igapó. La alta diversidad florística de los dos bosques se reflejó en una gran variación inter-específica a nivel local en $\delta^{13} \mathrm{C}$ y $\delta^{15} \mathrm{~N}$. Comparaciones pareadas revelaron que los valores de $\delta^{13} \mathrm{C}$ 
de madera y frutas y $\delta^{15} \mathrm{~N}$ de frutas fueron generalmente mayores que los valores obtenidos para las hojas de la misma planta. Los resultados sobre la contribución de diferentes fuentes de carbono a la biomasa del consumidor cambió de un modelo a otro en función a la variabilidad isotópica en las fuentes alimenticias. Discutimos las implicaciones de la variación en las fuentes alimenticias para el diseño de los protocolos de muestreo, la interpretación de las señales isotópicas, y el establecimiento de relaciones tróficas entre plantas y consumidores. Nuestros resultados destacan la importancia de la toma de muestras in situ para establecer líneas de base fiables de producción primaria para las redes tróficas locales.

Palabras clave: Isótopos estables, Igapó, Várzea, Frutas, Red trófica, Modelos de mezcla.

\section{Introduction}

The use of stable isotopes in ecology has increased steadily during the past three decades, and ecological applications are diverse in scope and scale (Dawson et al. 2002, Fry 2006, West et al. 2006). Stable isotope analysis has become a primary tool in food-web studies to depict production sources supporting consumers and to analyze food-web structure (Boecklen et al. 2011, Layman et al. 2012). Use of stable isotopes in food-web research relies on natural variation in the abundance of stable isotopes within components of the ecosystem (Peterson \& Fry 1987, Fry 2006).

Variation in the ratio of carbon stable isotopes $\left({ }^{13} \mathrm{C} /{ }^{12} \mathrm{C}\right.$ and indicated by $\delta^{13} \mathrm{C}$ ) in plants is commonly used to trace the origin of food assimilated by animals. Differential assimilation of the lighter ${ }^{12} \mathrm{C}$ isotope during photosynthesis, results in plants having $\delta^{13} \mathrm{C}$-depleted tissues relative to atmospheric $\mathrm{CO}_{2}$. Local abiotic factors (e.g., irradiance, elevation, atmospheric humidity, soil moisture, salinity, and $\mathrm{N}$ availability), as well as plant morphological traits, physiological processes, and genotype, influence ${ }^{13} \mathrm{C}$ discrimination to varying degrees (reviewed by Dawson et al. 2002, and Bowling et al. 2008). As a result, plants have distinctive $\delta^{13} \mathrm{C}$ signatures that can be traced as they are transferred to herbivores and other consumers at higher levels in the food web (DeNiro \& Epstein 1978, Fry \& Sherr 1984, McCutchan et al. 2003).

Nitrogen isotopic ratios $\left({ }^{15} \mathrm{~N} /{ }^{14} \mathrm{~N}\right.$ as indicated by $\left.\delta^{15} \mathrm{~N}\right)$ are commonly used to estimate trophic position of consumers in food webs because $\delta^{15} \mathrm{~N}$ accumulates incrementally from the base to the top of a food chain (Post 2002). $\delta^{15} \mathrm{~N}$ signatures of plants are largely influenced by the $\delta^{15} \mathrm{~N}$ of $\mathrm{N}$ sources (Handley $\&$ Raven 1992). Plants are generally $\delta^{15} \mathrm{~N}$ depleted relative to the soils in which they grow (Amundson et al. 2003), as most plants absorb inorganic forms of $\mathrm{N}$ from the soil. Spatial and temporal variation in $\mathrm{N}$ sources, as well as symbiotic associations and physiological mechanisms of $\mathrm{N}$ assimilation and allocation, cause variation in plant $\delta^{15} \mathrm{~N}$ isotopic signatures (reviewed by Evans 2001, Dawson et al. 2002). Differences among co-occurring species usually range from 0 to $10 \%$ (Evans 2001), with differences of $\sim 1 \%$ o being considered biologically significant (Handley \& Raven 1992).

Lowland floodplains of the Amazon Basin support large expanses of highly diverse forests that flood up to $10 \mathrm{~m}$ and as long as 8 months each year (Junk \& Piedade 2010). Fruiting phenology of most trees and liana species in flooded forests is synchronized with the annual flood (Parolin et al. 2004). This resource pulse attracts a diverse suite of frugivores, from birds, bats and monkeys to turtles and fishes (Goulding 1980, Barnett et al. 2005, Haugaasen \& Peres 2007, 2008, Correa \& Winemiller 2014). The high predictability of the flood pulse in the Amazon favors consumers capable of exploiting floodplain resources, therefore riparian terrestrial and aquatic food webs are subsidized by energy inputs from the flooded forest (Junk et al. 1997, Oliveira et al. 2006a, Junk \& Piedade 2010). Amazonian floodplain forests cover an extensive area, have high floristic diversity and provide important resources for diverse consumer taxa. Nonetheless, natural variation in $\delta^{13} \mathrm{C}$ and $\delta^{15} \mathrm{~N}$ in flooded forest plants has seldom been investigated, especially among samples from the same locality (e.g., Martinelli et al. 1991, 1992, 1994). Given that local abiotic factors as well as plant traits cause isotopic variation, how much variation in isotopic ratios is expected among species within a local plant community? What is the range of variation of tissues within an individual plant? How does this variation influence our ability to link basal producers and consumers in local food webs?

Stable isotope analysis of relative contributions of floodplain carbon sources to Amazon fishes rarely have accounted for natural variability in local plant communities (e.g., Oliveira et al. 2006a,b). Moreover, isotopic ratios of $\mathrm{C}_{3}$ terrestrial plants usually are assessed from very limited samples of leaves or composite sample of tree parts without consideration of variation within and among species or tissue types within a single plant (e.g., Araujo-Lima et al. 1986, Forsberg et al. 1993). Very little is known on isotopic variation between vegetative and reproductive tissues, despite the importance of fruit as food for large suites of invertebrates and vertebrates in both temperate and tropical ecosystems (Jordano 2000).

Here we assessed between-site, within-site and within-plant variation in $\mathrm{C}$ and $\mathrm{N}$ stable isotopes of woody plants in Amazonian flooded forests and investigated how such variation affects interpretations of trophic links between primary producers and aquatic consumers that feed heavily on foods derived from the flooded forest. Our objectives were to: 1) compare $\delta^{13} \mathrm{C}$ and $\delta^{15} \mathrm{~N}$ of woody plants from forests with contrasting watershed biogeochemistry and floristic composition (i.e., neutral, nutrient-rich white water várzea forest and acidic, nutrient-poor black water igapó forest; Worbes 1997); 2) assess the magnitude of within-site variation in $\delta^{13} \mathrm{C}$ and $\delta^{15} \mathrm{~N}$ of leaves and fruits; 3) determine within-plant variation in $\delta^{13} \mathrm{C}$ and $\delta^{15} \mathrm{~N}$ of leaf and fruit tissues; and 4) test the influence of isotopic variation on a mixing model predicting the relative contribution of $\mathrm{C}$ sources to the biomass of a fruit-eating fish species. We hypothesized that 1) woody plants of white-water and black-water flooded forests have different $\delta^{13} \mathrm{C}$ and $\delta{ }^{15} \mathrm{~N}$ signatures; 2) within-site variation in $\delta^{13} \mathrm{C}$ in single floodplain forest sites is smaller than the variation previously reported at a regional scale in the central Amazonia (Martinelli et al. 1991); 3) non-photosynthetic tissues, particularly fruits, have different isotopic signatures than leaves from the same plant; and 4) isotopic variation changes the predicted contribution of different $\mathrm{C}$ sources to the consumer biomass. 


\section{Materials and Methods}

\section{Study sites}

We sampled floodplain forests in two areas of the western Amazon (southern Colombia) with distinct biogeochemistry but similar climate. The first forest (várzea, which refers to a forest inundated by sediment-laden white water (Sioli 1984)) is located on the floodplain between the Amazon and LoretoYacu rivers. Sampling was conducted during the middle of the rising-water season (February to March, 2007) in the evergreen flooded forest surrounding three interconnected lakes within the floodplain (hereafter these will be referred to as the "Tarapoto Lakes complex"). Sampled lakes included Lago Shaman $\left(3^{\circ} 47^{\prime} \mathrm{S}, 70^{\circ} 24^{\prime} \mathrm{W}\right)$, Lago Tarapoto (sampled at Poza de Soraida, $\left.3^{\circ} 49^{\prime} \mathrm{S}, 70^{\circ} 28^{\prime} \mathrm{W}\right)$, and Cocha Larga $\left(3^{\circ} 49^{\prime} \mathrm{S}, 70^{\circ}\right.$ $\left.28^{\prime} \mathrm{W}\right)$. Rainfall is estimated at $3325 \mathrm{~mm}$ year-1, average monthly precipitation ranges from $180 \pm 80 \mathrm{~mm}$ to $370 \pm 100$ $\mathrm{mm}$, and average monthly temperature ranges from $23-28{ }^{\circ} \mathrm{C}$ (1973-2004; Duque et al. 1997). The annual flooding regime imposes changes in water level of up to $12 \mathrm{~m}$ (Duque et al. 1997). Water in these lakes, although dark in color, have physicochemical properties similar to those of other upper whitewater Amazonian floodplain lakes $(\mathrm{pH}$ ranges from 6.2-6.9,

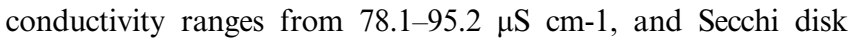
transparency ranges from $0.4-0.8 \mathrm{~m}$; Sioli 1984). Soil in the floodplain is composed of fine sand over sedimentary rocks formed from a sandy base (Botero 1999). Vegetation corresponds to a seasonally flooded, medium-height forest over alluvial deposits of Andean origin (Botero 1999). Plant species richness in this forest has not been estimated.

The second forest (igapó, which refers to a forest inundated by acidic water, darkly stained with dissolved humic compounds and containing negligible amounts of dissolved salts (Sioli 1984)) is located in the lower Apaporis River, a large black-water river that drains the southwestern portion of the ancient Guyana Shield. Sampling was conducted during the high-and falling-water seasons (from late May to early October 2009) in the evergreen flooded forest along the river and in an adjacent oxbow lake (Lago Taraira, $1^{\circ} 09^{\prime} \mathrm{S}, 69^{\circ} 29^{\prime} \mathrm{W}$ ). Rainfall is estimated at $3836 \pm 486.3 \mathrm{~mm}$ year-1, average monthly precipitation ranges from $258 \pm 92.3 \mathrm{~mm}$ to $370 \pm 100 \mathrm{~mm}$, and average monthly temperature ranges from $22.5-27.3{ }^{\circ} \mathrm{C}$ (Correa 2003). The annual flooding regime causes a 9-m fluctuation in water level, flooding the forest for up to 7-8 months of each year (Correa 2008). Water in the Apaporis has physicochemical properties similar to those of other black-water rivers in the Amazon Basin ( $\mathrm{pH}$ ranges from 5.2-6.5, conductivity ranges from 5.9-7.4 $\mu \mathrm{S} \mathrm{cm-1,} \mathrm{and} \mathrm{Secchi} \mathrm{disk} \mathrm{transparency} \mathrm{ranges}$ from $0.6-1.3 \mathrm{~m}$; Sioli 1984). Soil in the floodplain is characterized as infertile white clay (Defler \& Defler 1996). The vegetation corresponds to a seasonally flooded, medium-height forest growing on sand deposits and a Precambrian rock basement (Hoorn 2006). Plant species richness in the flooded forest is estimated at 215 species, $65 \%$ of which are not shared with other forest types in the area (Clavijo et al. 2009).

\section{Sample collection}

We collected samples for analysis of $\delta^{13} \mathrm{C}$ and $\delta^{15} \mathrm{~N}$ stable isotope ratios from 20 to 30 species of woody plants, at each site. Species included trees, shrubs, vines, and hemi-epiphytes that were common at each site, most of which were bearing fruits at the time when sampling was conducted. We conducted sampling inside the flooded forest and along the forest edge using a canoe; samples from the canopy were obtained by climbing. In the várzea site, samples of fruits, leaves, and trunk wood (which included bark and sapwood) were collected from individual plants in order to assess within-plant and interspecific variation. We included wood samples in our withinplant comparisons to use it as a reference since wood is reported to be ${ }^{13} \mathrm{C}$-enriched relative to leaves (Badeck et al. 2005). We also collected samples of fruits and leaves in the igapó site. Except for one shrub species (Symmeria paniculata), none of the sampled species were shared between the two sites. Botanical vouchers for all species were deposited in the Colombian Amazon Herbarium (COAH), Instituto Amazónico de Investigaciones Científicas-Sinchi, Colombia. Taxonomic identifications follow APG III (Haston et al. 2009).

We choose the frugivorous fish species Mylossoma duriventre (Serrasalmidae, Characiformes) because it is highly abundant in várzea forests and fruits are the most important component of its diet during the flood season (S.B. Correa, unpublished results). We collected samples of fish, seston, leaves of four $\mathrm{C}_{3}$ aquatic macrophytes species (Eichornia crassipes, Pistia stratiotes, Ceratopteris pteridoides, and Phyllanthus fluitans), and leaves of a $\mathrm{C}_{4}$ grass species (Paspalum repens) for isotopic analysis. We sampled fish with gill nets deployed within the flooded forest. Immediately after euthanasia, we removed a sample of approximately $2 \mathrm{~cm}^{2}$ of muscle tissue from the dorsal region of the flank below the dorsal fin. Scales and skin we removed before preservation. We sampled seston with a plankton net, filtered each sample onto pre-combusted Whatman GF/F filters and dried it at $60^{\circ} \mathrm{C}$ for $24 \mathrm{~h}$. We collected several seston samples, however all but one sample degraded due to improper storage after the samples were dried.

We preserved samples in $\mathrm{NaCl}$ immediately after collection. This is an effective preservation technique for remote field settings where ice is not available, and has been shown to have a negligible effect on $\delta^{13} \mathrm{C}$ and $\delta^{15} \mathrm{~N}$ of fish muscle tissue (Arrington \& Winemiller 2002). We rinsed samples twice with deionized water, soaked them over a $48 \mathrm{~h}$ period and dried them at $60^{\circ} \mathrm{C}$ for $24 \mathrm{~h}$ (fish muscle) or $48 \mathrm{~h}$ (plant tissue). We grinded dried samples to a fine powder using an electric grinder (Wing-L-Bug, Pike Technologies). We weighed samples to the nearest $0.1 \mathrm{mg}$ using an analytical balance (Adventurer, Ohaus) and send them to the Analytical Chemistry Laboratory, Institute of Ecology, University of Georgia, for analysis of carbon and nitrogen percentage composition and stable isotope ratios. Carbon and nitrogen isotope values represent the deviation from the isotopic ratios of Pee Dee Belemnite limestone and atmospheric nitrogen, respectively, in delta notation: $\delta^{13} \mathrm{C}$ or $\delta^{15} \mathrm{~N}=((\mathrm{R}$ sample / $\mathrm{R}$ standard $)-1) \mathrm{x}$ 1000 . Precision of the isotopic analysis was $\leq 0.11 \%$ measured as the standard deviation among bovine reference samples. Because all samples were collected while the forest was flooded, isotopic variation due to seasonality was not expected. Likewise, within-site spatial variation was expected to be low because sampling was confined to a single floodplain location containing relatively consistent plant composition.

\section{Statistical analyses}

We compared mean values of $\delta^{13} \mathrm{C}$ and $\delta^{15} \mathrm{~N}$ of leaves and fruits between sites using anova and within-sites using t-tests. 
We compared paired tissue samples taken from a single individual plant with non-parametric Wilcoxon signed rank tests in order to test the null hypothesis that isotopic signatures $\left(\delta^{13} \mathrm{C}, \delta^{15} \mathrm{~N}\right)$ are equal between tissues. In the event of tied ranks, $P$-values were calculated from the exact null distribution using the COIN package of $\mathrm{R}$ (Hothorn et al. 2008). We conducted Spearman's rank correlation to determine between tissue correlations in $\delta^{13} \mathrm{C}$ and $\delta^{15} \mathrm{~N}$ measured from the same plants. Statistical analyses were conducted in $\mathrm{R}$ (version 2.15.1, R-Core-Development-Team 2012).

To demonstrate the importance of accounting for isotopic interspecific- and within-plant variability in food-web research, we ran a series of mixing models to assess the relative contribution of forest plant material to the biomass of a primarily fruit-eating fish (Appendix 1; standard length ranging from 86 to $145 \mathrm{~mm} ; N=24$ ). Plant material included in the models were forest fruits and leaves of 20 woody plant species (both tissues collected from the same individuals) (Appendix 2), leaves of four $\mathrm{C}_{3}$ aquatic macrophyte species $(N=8)$, leaves of a $\mathrm{C}_{4}$ grass $(N=2)$, and seston $(N=1)$. These sources represent the main primary production sources in Amazonian floodplains (Benedito-Cecilio et al. 2000, Oliveira et al. 2006b).

We used MixSIR (Version 1.0.4, Moore \& Semmens 2008), a software package that allows for inclusion of isotopic variation of consumers, sources, and trophic fractionation rather than relying only on mean values as input. We followed a similar approach to that of Moore and Semmens (2008) in which we manipulated ranges of variation in mixing models. Because we were mostly interested in assessing the influence of source variation on model results, we only changed variation for sources and did not vary fractionation values or consumer isotopic ratios. Model 1: included 4 sources (fruits, $\mathrm{C}_{3}$ aquatic macrophyte leaves, $\mathrm{C}_{4}$ grass leaves, seston) and one standard deviation (SD) per source. Model 2: resembled model 1, but we increased the isotopic variability of each source from $1 \mathrm{SD}$ to 2 SD. Model 3: resembled model 2, but we eliminated isotopic variation in fruits $(S D=0)$. Model 4: resembled model 1 , but we replaced fruits with woody plant leaves. Model 5: resembled model 4, but we eliminated isotopic variability in leaves $(\mathrm{SD}=0)$. Model 6: resembled model 1, but we eliminated isotopic variation in all sources $(\mathrm{SD}=0)$. Although unrealistic, we included models without isotopic variation of sources $(\mathrm{SD}=0)$ to demonstrate the various effects of isotopic variation on model results as other popular software packages build mixing models on mean values without accounting for variation (e.g., IsoSource, Phillips \& Gregg 2003). Fractionation values used in mixing models $(\mathrm{N}=4.39 \pm 0.05 ; \mathrm{C}=0.06$ \pm 0.08) follow those in German \& Miles (2010) calculated from plasma of a tropical herbivorous fish.

\section{Results}

\section{Between-site isotopic variation}

Despite differences in biogeochemistry and floristic composition, the two sites had similar mean $\delta^{13} \mathrm{C}$ for both leaves and fruits. Mean $\delta^{13} \mathrm{C}$ of leaves from the várzea (mean $\pm \mathrm{SD},-32.05$ $\pm 2.10 \%$ ) was only marginally lower than the mean from the igapó (mean $\pm \mathrm{SD},-30.63 \pm 1.86 \%$; t-test $=-2.00, \mathrm{df}=$ $36, P=0.06)$. Fruits from both sites had similar mean $\delta^{13} \mathrm{C}$ (mean $\pm \mathrm{SD}$, várzea: $-31.14 \pm 2.45 \%$; igapó: $-30.18 \pm 1.91 \%$; t-test $=-1.44$, df $=42, P=0.16$ ). Leaves and fruits from the várzea, however, had greater $\delta^{13} \mathrm{C}$ variation (Figure 1).

For both leaves and fruits, mean $\delta^{15} \mathrm{~N}$ was lower for the várzea (mean $\pm \mathrm{SD}$, leaves: $1.64 \pm 1.41 \%$; fruits: $2.33 \pm$ $1.27 \%$ ) than igapó (mean $\pm \mathrm{SD}$, leaves: $4.43 \pm 1.02 \%$; fruits: $3.92 \pm 1.53 \%$; leaves-t-test $=-6.67, \mathrm{df}=36, \mathrm{P}<0.0001$; fruits-t-test $=-3.77, \mathrm{df}=42, P<0.0001$; respectively). Fruits from the várzea revealed less variation in $\delta^{15} \mathrm{~N}$ relative to those from the igapó (Fig 2c,g).

$\mathrm{C}: \mathrm{N}$ ratios of leaves were higher in the várzea than in the igapó (mean $\pm \mathrm{SD}, 28.17 \pm 7.79$ and $19.16 \pm 4.91$, respectively; t-test $=3.41, \mathrm{df}=36, P<0.001$ ). No differences in $\mathrm{C}: \mathrm{N}$ ratios of fruits, however, were detected between sites (mean \pm SD, $38.55 \pm 16.62$ and $40.79 \pm$ 19.94, respectively; t-test $=-0.41, \mathrm{df}=42, P=0.69)$.

\section{Within-site interspecific variation}

Within each site, $\delta^{13} \mathrm{C}$ and $\delta^{15} \mathrm{~N}$ of both leaves and fruits was variable among species. In the várzea, $\delta^{13} \mathrm{C}$ of leaves of 28 species (Appendix 2) ranged 8.4\%o (Figure 1a,b), whereas half of the species had values that ranged at least 3\%o (Figure 1a). $\delta^{13} \mathrm{C}$ of fruits of 22 species (Appendix 2) revealed greater variation than leaves (range $=11.2 \%$, Figure $1 \mathrm{c}, \mathrm{d}$ ), and half of the species had fruit samples that varied by at least $3 \%$ (Figure 1c). The range in $\delta^{13} \mathrm{C}$ of leaves from 10 species from the igapó site (Appendix 3) was 5.1\%o (Figure 1e,f), with half of the species varying by at least $3.3 \%$ (Figure $1 \mathrm{e}$ ). $\delta^{13} \mathrm{C}$ values of fruits from 22 species (Appendix 3) ranged 6.4\% (Figure 1g,h), with half of the species varying by at least $2.1 \%$ (Figure $1 \mathrm{~g}$ ).

$\delta^{15} \mathrm{~N}$ of leaves from the várzea ranged $5.1 \%$ (Figure $2 \mathrm{a}, \mathrm{b}$ ), with half of the species ranging by at least $1.8 \%$ (Figure $2 a$ ). $\delta^{15} \mathrm{~N}$ of fruits ranged $4.1 \%$ (Figure $2 \mathrm{c}, \mathrm{d}$ ), with half of the species ranging by at least $2.2 \%$ (Figure $2 \mathrm{c}$ ). $\delta^{15} \mathrm{~N}$ of leaves from the igapó ranged 3.2\% (Figure 2e,f), with half of the species varying $<1 \%$ (Figure $2 \mathrm{e}$ ). $\delta^{15} \mathrm{~N}$ of fruits was more variable with a range of $5.8 \%$ (Figure $2 \mathrm{~g}, \mathrm{~h}$ ), and fruits of half of the species varied by at least $1.6 \%$ (Figure $2 \mathrm{~g}$ ).

\section{Within-plant isotopic variation}

Paired comparisons of different tissues sampled from individual plants from the várzea site showed that, as expected, $\delta^{13} \mathrm{C}$ of wood was generally ${ }^{13} \mathrm{C}$-enriched relative to leaves (Wilcoxon signed rank test, $\mathrm{W}=131, n=18, P<0.05$ ), with an average difference of $1.02 \%$. Wood of seven species, however, was ${ }^{13} \mathrm{C}$-depleted by $\leq 0.5 \%$ relative to leaves, and wood of one species was ${ }^{13} \mathrm{C}$-depleted by $\leq 1.8 \%$ relative to leaves (Figure $3 \mathrm{a}) . \quad \delta^{13} \mathrm{C}$ of wood was positively and significantly correlated with that of corresponding leaves when all taxa were analyzed (Spearman's rank correlation, rho $=0.66$, $P<0.05)$.

$\delta^{15} \mathrm{~N}$ of wood generally was ${ }^{15} \mathrm{~N}$ enriched relative to leaves; however, the difference $(0.73 \%$ ) was not statistically significant (Wilcoxon signed rank test, $\mathrm{W}=126, \mathrm{Z}=1.76, n=18, P=$ 0.08 ). Only a few species had leaves that were ${ }^{15} \mathrm{~N}$ enriched relative to wood. In three of these species, leaf signatures were enriched as much as nearly $2 \%$ (Figure $3 \mathrm{~b}$ ). $\delta^{15} \mathrm{~N}$ of wood was not correlated with that of corresponding leaves (Spearman's rank correlation, rho $=0.22, P=0.39)$. Wood $\mathrm{C}: \mathrm{N}$ ratios were consistently greater than those of leaves across all species 


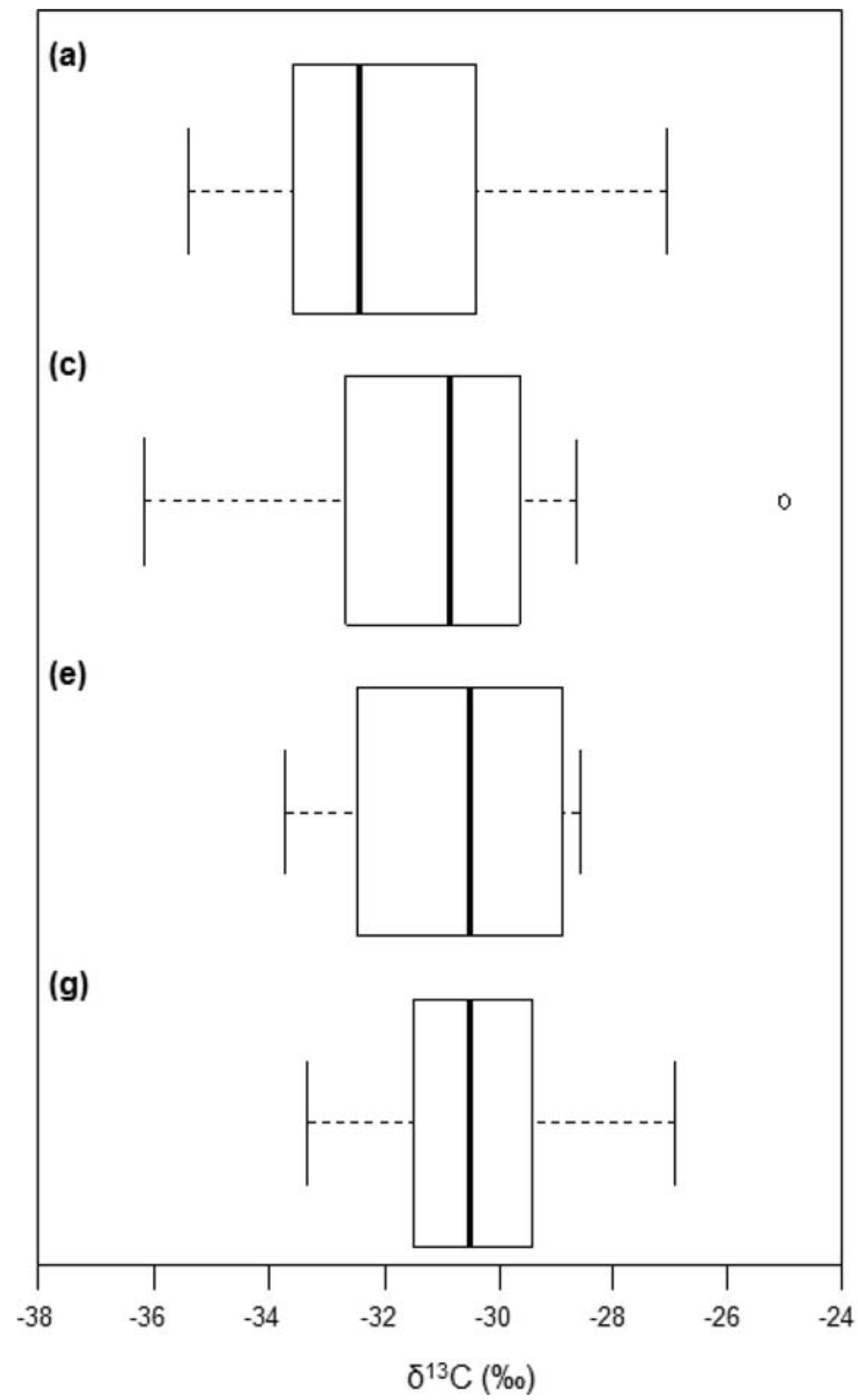

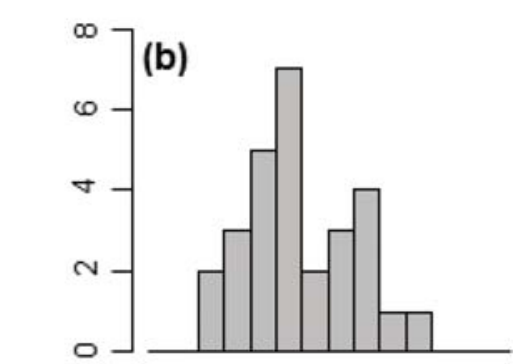
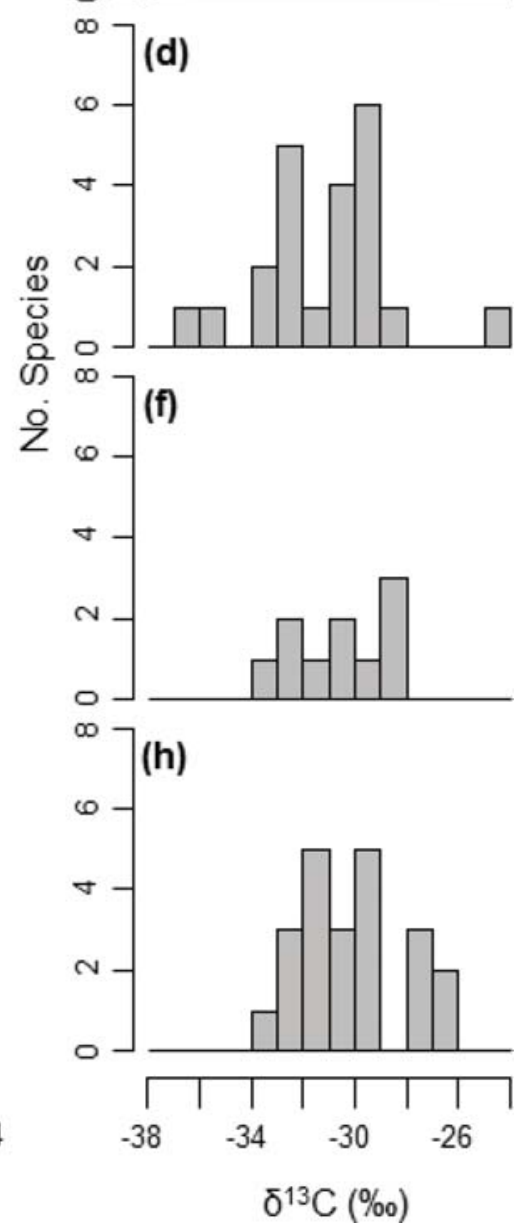

Figure 1. Boxplot and frequency distributions of $\delta^{13} \mathrm{C}$ of co-occurring plant species from two western Amazonian flooded forest sites with different biogeochemistry: Tarapoto Lakes complex (várzea): (a, b) leaves (28 species), (c, d) fruits (22 species); Lower Apaporis River (igapó): (e, f) leaves (10 species), (g, h) fruits (22 species). The box indicates the distribution of $50 \%$ of the species.

(Wilcoxon signed rank test, $\mathrm{W}=171, n=18, P<0.0001$ ), with an average difference of $14.7(1.4-75.3)$.

$\delta^{13} \mathrm{C}$ of fruits generally was ${ }^{13} \mathrm{C}$ enriched relative to leaves (Wilcoxon signed rank test, $\mathrm{W}=161, n=20, P<0.04$ ), with an average difference of $0.68 \%$. Four species, however, have ${ }^{13} \mathrm{C}$ enriched leaves relative to fruits; in one of them, the difference was nearly $3 \%$ (Figure $4 a$ ). $\quad \delta^{13} \mathrm{C}$ of fruits was positively correlated with that of corresponding leaves (Spearman's rank correlation, rho $=0.82, P<0.0001$ ).

$\delta^{15} \mathrm{~N}$ of fruits generally was ${ }^{15} \mathrm{~N}$ enriched relative to leaves (Wilcoxon signed rank test, $\mathrm{W}=179, n=20, P<0.005$ ), with a difference of $1.02 \%$. A few species had leaves that were ${ }^{15} \mathrm{~N}$ enriched relative to fruits; in two species, the difference was nearly $1.5 \%$ (Figure $4 \mathrm{~b}$ ). $\delta^{15} \mathrm{~N}$ of fruits was weakly correlated with that of corresponding leaves (Spearman's rank correlation, rho $=0.44, P=0.055)$. Fruit $\mathrm{C}: \mathrm{N}$ ratios generally were greater than those of leaves from the same plant (Wilcoxon signed rank test, $\mathrm{W}=173, n=20, P<0.01$ ), with an average difference of 9.9 (difference values ranged from -6.9 to 44.9 ). A few species, however, had fruits with lower $\mathrm{C}: \mathrm{N}$ ratios than leaves (Appendix 2).

\section{Influence of plant isotopic variation on estimates of plant contributions to consumers}

Estimated relative contributions of primary production sources to Mylossoma duriventre in the várzea of the Tarapoto Lake's complex differed among models as a function of 

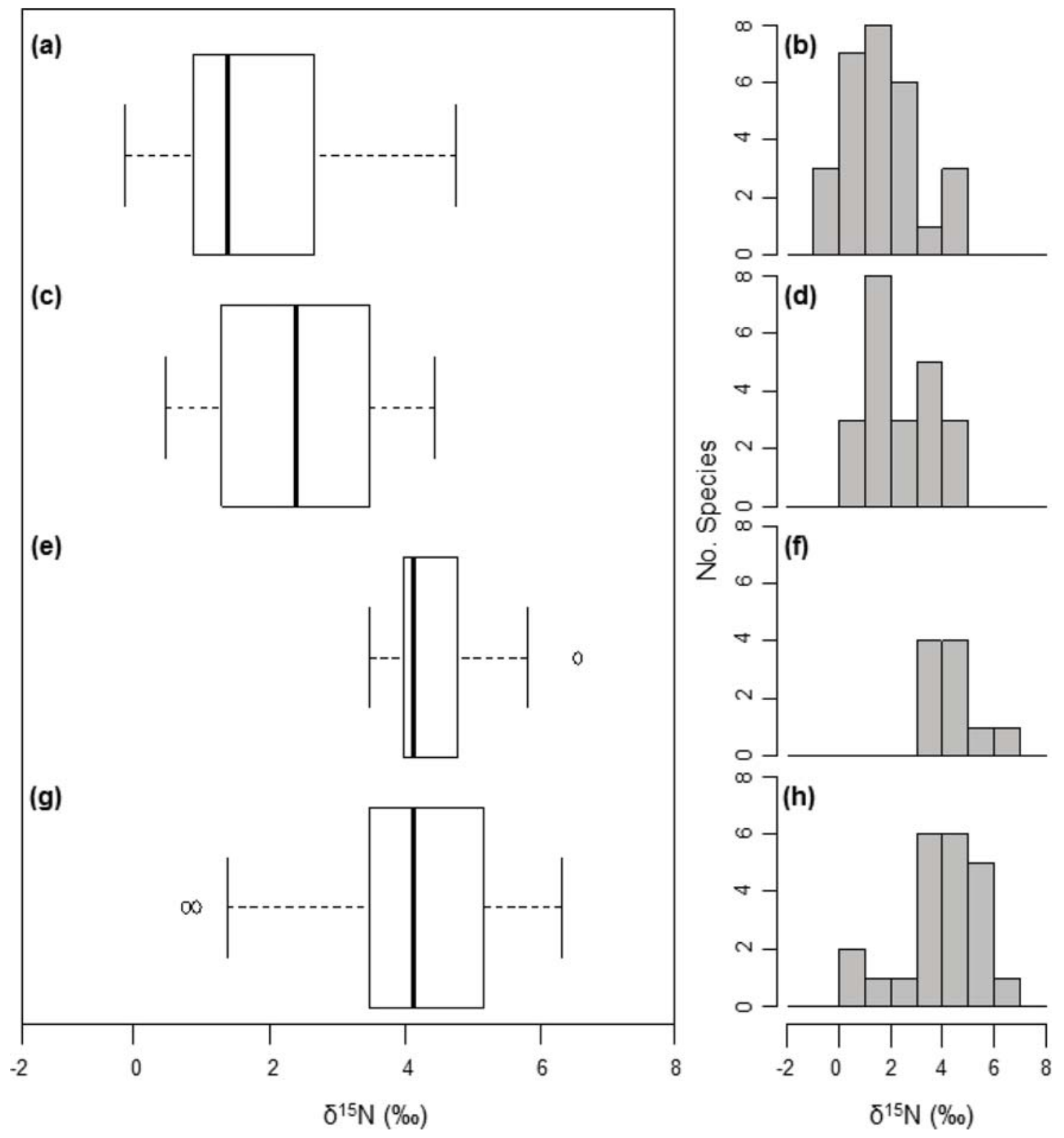

Figure 2. Boxplot and frequency distributions of $\delta^{15} \mathrm{~N}$ of co-occurring plant species from two western Amazonian flooded forest sites with different biogeochemistry: Tarapoto Lakes complex (várzea): (a, b) leaves (28 species), (c, d) fruits (22 species); Lower Apaporis River (igapó): (e, f) leaves (10 species), $(\mathbf{g}, \mathbf{h})$ fruits (22 species). The box indicates the distribution of $50 \%$ of the species.

source variability. Fruits made the highest contribution to M. duriventre's biomass according to MixSIR models that account for variation in isotopic signatures (1 and 2 SD). The model with increased variability (2 SD), however, reduced the predicted median contribution of fruits by $15 \%$ while increasing the median contribution of a $\mathrm{C}_{4}$ aquatic grass by $2 \%$. When variability in isotopic ratios of fruit was eliminated from the model $(\mathrm{SD}=0)$, the predicted median contribution of fruit shifted to zero and $\mathrm{C}_{3}$ aquatic macrophytes became the most important food source. Model fit, however, was low (Table 1). Similar patterns were found in models in which fruits were replaced by leaves (Table 1). A model without variation in isotopic ratios of all sources failed to find a feasible solution for source contribution to the consumer (results not shown).

\section{Discussion}

\section{Between-site variation}

Contrary to our expectation, the two flooded forest sites analyzed in this study had similar mean values for leaves as well as for fruits, despite significant within-site variation in $\delta^{13} \mathrm{C}$. The two sites have similar climatic regimes (precipitation, humidity, temperature, and hydrological cycle) but different biogeochemistry. The várzea forest in the Tarapoto Lakes complex grows over fine-sand sediments accumulated over sedimentary rocks of Andean origin (Botero 1999) while the igapó forest in the lower Apaporis River grows on white-clay soil (Defler \& Defler 1996) derived from Miocene sand deposits overlying a Precambrian rock basement (Hoorn 2006). In a study of basin-wide variation in $\delta^{13} \mathrm{C}$ of Amazon terra firme 

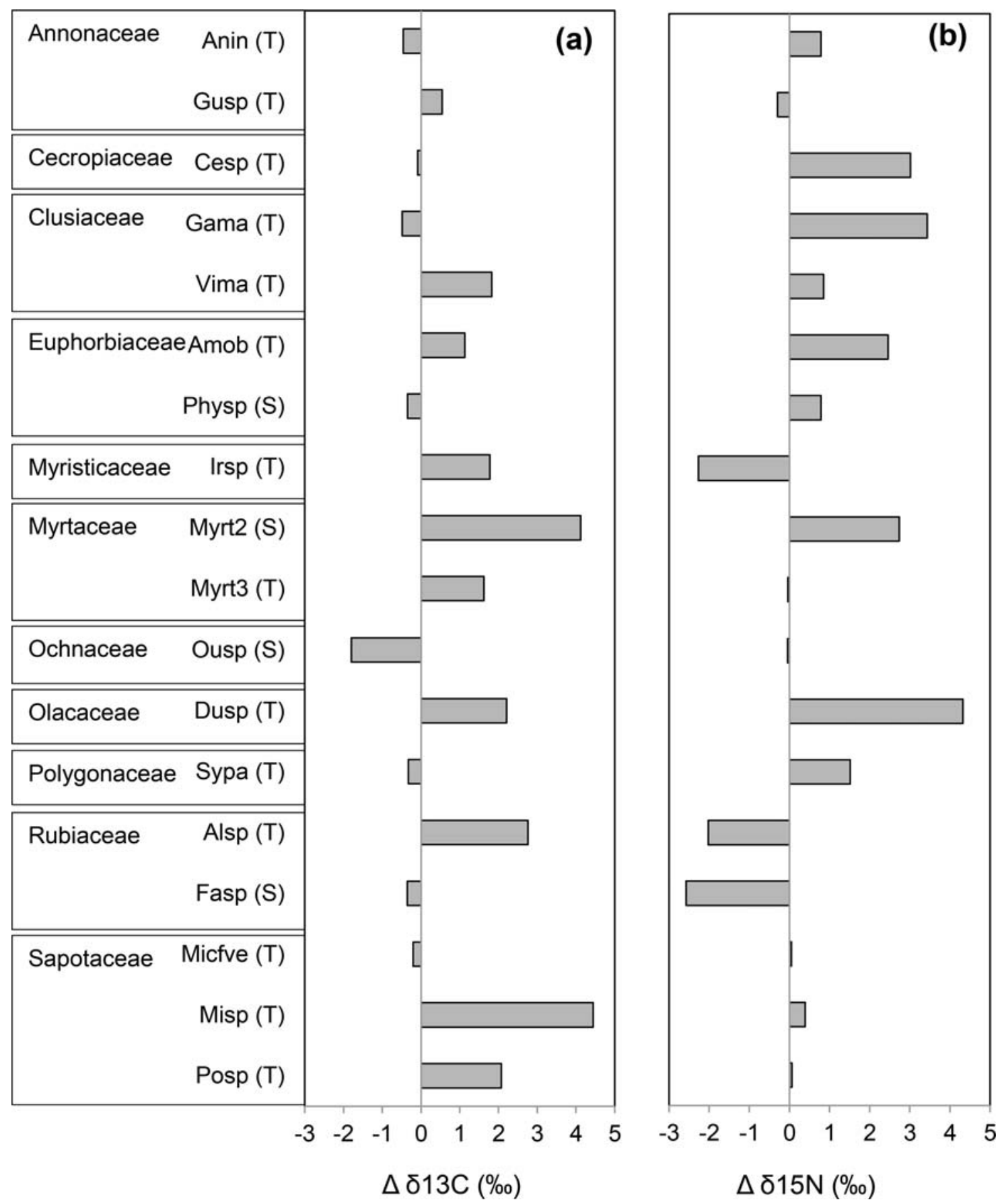

Figure 3. Isotopic variation between trunk wood and leaf tissue of 18 co-occurring plant species from the flooded forest (várzea) of the Tarapoto Lakes complex, western Amazonia. (a) $\Delta \delta^{13} \mathrm{C}$ (Wood $\delta^{13} \mathrm{C}$ - Leaf $\left.\delta^{13} \mathrm{C}\right)$, (b) $\Delta \delta^{15} \mathrm{~N}$ (Wood $\delta^{15} \mathrm{~N}$ - Leaf $\left.\delta^{15} \mathrm{~N}\right)$. Positive values indicate that wood has heavier isotopic signatures with respect to leaves from the same individual plant. Species codes follow those in Appendix 2. Plant growth habit is indicated in parenthesis $(\mathrm{T}=$ tree, $\mathrm{S}=$ shrub).

forests, Fyllas et al. (2009) found that soil fertility (Ca, K, Mg, and $\mathrm{P}$ ) was the best predictor of foliar $\delta^{13} \mathrm{C}$. In contrast to terra firme forests of the Amazon, soil characteristics in floodedforests may not have a strong influence on plant $\delta^{13} \mathrm{C}$. The isotopic composition of plants in additional flooded forest sites, however, should be examined before making a generalization. Mean foliar $\delta^{13} \mathrm{C}$ values in these two flooded forests are also congruent with those of terra firme forests in the Amazon Basin (Table 2), despite the great differences in floristic composition of flooded and non-flooded forests even within a given locality (Campbell et al. 1986, Haugaasen \& Peres 2006, Clavijo et al. 2009).

Woody plants from the igapó of the lower Apaporis had higher mean $\delta^{15} \mathrm{~N}$ values for leaves $(2.8 \%$ ) and fruits $(1.6 \%$ ) than plants from the várzea. Differences in mean annual precipitation (MAP) and mean annual temperature (MAT) have been identified as main factors contributing to inter-site variation in site-averaged foliar $\delta^{15} \mathrm{~N}$ at a global scale 


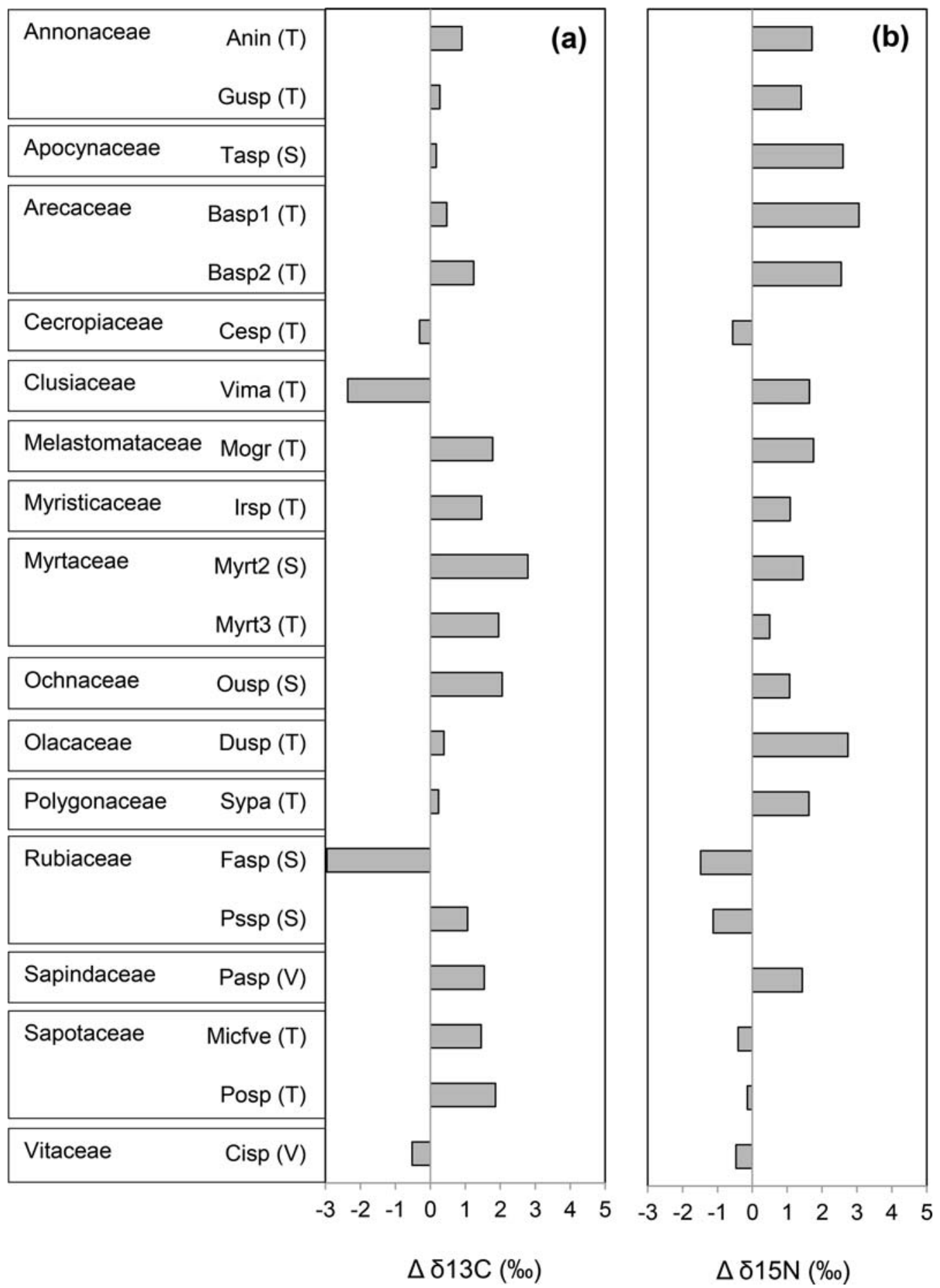

Figure 4. Isotopic variation between fruits (pulp and seeds) and leaves of 20 co-occurring plant species from the flooded forest (várzea) of the Tarapoto Lakes complex, western Amazonia. (a) $\Delta \delta^{13} \mathrm{C}$ (Fruit $\delta^{13} \mathrm{C}$ - Leaves $\delta^{13} \mathrm{C}$ ), (b) $\Delta \delta^{15} \mathrm{~N}$ (Fruit $\delta^{15} \mathrm{~N}-$ Leaves $\delta^{15} \mathrm{~N}$ ). Positive values indicate that fruits had heavier isotopic signatures with respect to leaves from the same individual plant. Species codes follow those in Appendix 2. Plant growth habit is indicated in parenthesis $(\mathrm{T}=$ tree, $\mathrm{S}=$ shrub, $\mathrm{V}=$ vine).

(Handley et al. 1999, Amundson et al. 2003). The two forest sites analyzed in this study, however, have very high and similar MAP (3.3 m and $3.8 \mathrm{~m}$ in the várzea and igapó, respectively). MAT in the igapó site $\left(25^{\circ} \mathrm{C}\right)$ falls within the range of mean monthly temperature $\left(23-28^{\circ} \mathrm{C}\right)$ registered at the várzea site. Thus it is unlikely that such relatively small differences in precipitation and temperature are causing the observed differences in isotopic signatures.
However, in addition to climate, plant $\delta^{15} \mathrm{~N}$ vary as a function of soil $\delta^{15} \mathrm{~N}$ (Handley \& Raven 1992). In a study of soil chemistry in Amazon flooded forests sampled during the dry season, Furch (1997) found no significant differences in total $\mathrm{N}$ content between a várzea and an igapó forest site. Nitrogen content, however, was higher in the humic layer in the várzea soil, but the top mineral layer $(0-10 \mathrm{~m})$ in the igapó site contained twice the amount of $\mathrm{N}$ than the same layer in the 
Table 1. Median and 5th-95th percentile ranges (in parentheses) of source contributions to biomass of a flooded-forest frugivorous fish (Mylossoma duriventre) estimated from MixSIR mixing models with uninformative priors. 10 x $10^{6}$ interactions were carried out per model. $\dagger<1000$ posterior draws indicates poor model fit. MIR $=$ maximum importance ratio $<0.01$ indicates good model fit (Moore and Semmens 2008$)$. SD $=$ standard deviation. NA $=$ not applicable.

\begin{tabular}{lcccccc}
\hline Model variability & Fruits & Leaves & $\mathbf{C}_{\mathbf{3}}$ aquatic macrophytes & $\mathbf{C}_{\mathbf{4}}$ aquatic grass & Seston & MIR \\
\hline 1) $1 \mathrm{SD}$ & $0.82(0.78-0.86)$ & NA & $0.01(0.00-0.02)$ & $0.16(0.13-0.20)$ & $0.01(0.00-0.03)$ & 0.003 \\
2) 2SD & $0.67(0.58-0.76)$ & NA & $0.03(0.00-0.11)$ & $0.18(0.12-0.24)$ & $0.10(0.01-0.22)$ & 0.000 \\
3) Fruit SD $=0$ & $0(0.00-0.01)$ & NA & $0.83(0.82-0.85)$ & $0.17(0.15-0.18)$ & $0(0.00-0.01)$ & $0.042 \dagger$ \\
4) 1SD & NA & $0.76(0.73-0.79)$ & $0.01(0.00-0.03)$ & $0.23(0.20-0.25)$ & $0.01(0.00-0.03)$ & 0.004 \\
5) Leaf SD $=0$ & NA & $0(0.00-0.01)$ & $0.83(0.82-0.85)$ & $0.16(0.15-0.17)$ & $0(0.00-0.01)$ & $0.044 \dagger$ \\
\hline
\end{tabular}

Table 2. Foliar $\delta{ }^{13} \mathrm{C}$ (mean $\pm \mathrm{SD}$ ) reported from single forest sites in the Amazon Basin. $N=$ number of samples analyzed, followed by the number of species in parenthesis. Forest layer: $\mathrm{C}=$ canopy, $\mathrm{U}=$ understory, $\mathrm{LC}=$ lower canopy, $\mathrm{UC}=$ upper canopy. Source: $1=\mathrm{Medina}$ and Minchin (1980), 2 = Ometo et al. (2006), 3 = Martinelli et al. (1998).

\begin{tabular}{|c|c|c|c|c|c|c|}
\hline$\delta{ }^{13} \mathbf{C}$ & $N$ & Forest layer & Forest type & Region & Country & Source \\
\hline$-32.1 \pm 2.1 \%$ & $28(28)$ & $\mathrm{C} \& \mathrm{U}$ & Várzea & Western Amazonia & Colombia & This study \\
\hline$-30.6 \pm 1.9 \%$ & $24(10)$ & $\mathrm{C} \& \mathrm{U}$ & Igapó & Western Amazonia & Colombia & This study \\
\hline$-28.7 \pm 1.7 \%$ & $5(5)$ & $\mathrm{UC}$ & Terra-firme & Western Amazonia & Venezuela & 1 \\
\hline$-34.3 \pm 1.5 \%$ & $5(5)$ & $\mathrm{LC}$ & Terra-firme & Western Amazonia & Venezuela & 1 \\
\hline$-30.5 \pm 1.4 \%$ & $4(4)$ & $\mathrm{UC}$ & Caatinga & Western Amazonia & Venezuela & 1 \\
\hline$-33.4 \pm 1.5 \%$ & $9(9)$ & $\mathrm{LC}$ & Caatinga & Western Amazonia & Venezuela & 1 \\
\hline$-35.2 \pm 1.2 \%$ & $11(11)$ & $\mathrm{U}$ & Caatinga & Western Amazonia & Venezuela & 1 \\
\hline$-31.9 \pm 2.2 \%$ & $40(\mathrm{n} / \mathrm{a})$ & $\mathrm{C} \& \mathrm{U}$ & Terra-firme & Central Amazonia (Roraima) & Brazil & 2 \\
\hline$-32.2 \pm 2.5 \%$ & $133(\mathrm{n} / \mathrm{a})$ & $\mathrm{C} \& \mathrm{U}$ & Terra-firme & Central Amazonia (Amazonas) & Brazil & 2 \\
\hline$-32.6 \pm 2.7 \%$ & $42(\mathrm{n} / \mathrm{a})$ & $\mathrm{C} \& \mathrm{U}$ & Terra-firme & Central Amazonia (Amazonas) & Brazil & 2 \\
\hline$-32.8 \pm 2.2 \%$ & $150(\mathrm{n} / \mathrm{a})$ & $\mathrm{C} \& \mathrm{U}$ & Terra-firme & Central Amazonia (Pará) & Brazil & 2 \\
\hline$-32.1 \pm 2.6 \%$ & $280(\mathrm{n} / \mathrm{a})$ & $\mathrm{C} \& \mathrm{U}$ & Terra-firme & Central Amazonia (Pará) & Brazil & 2 \\
\hline$-32.1 \pm 1.5 \%$ & $208(\approx 100)$ & $\mathrm{C}$ & Terra-firme & Southern Amazonia (Rondônia) & Brazil & 3 \\
\hline
\end{tabular}

várzea site. Soils of various natural ecosystems have increased ${ }^{15} \mathrm{~N}$ enrichment along the vertical profile (Handley \& Raven 1992). Thus, perhaps igapó plants are using $\mathrm{N}$ from a deeper ${ }^{15} \mathrm{~N}$ enriched pool. Lastly, differences in watershed biogeochemistry may also influence differences in plant $\delta^{15} \mathrm{~N}$ between our sampled sites. For instance, terra firme forest growing on white sand, which are $\mathrm{N}$ limited, have significantly lower foliar $\delta^{15} \mathrm{~N}$ relative to forests growing on other soil types in the Amazon region, including várzea forests (Martinelli et al. 1999). Analysis of the isotopic composition of várzea and igapó soils from multiple sites would help elucidate causes of intersite differences in plant $\delta^{15} \mathrm{~N}$.

\section{Interspecific isotopic variation}

Natural variation in $\delta^{13} \mathrm{C}$ among flooded forest plants has seldom been investigated, especially among samples from the same locality. Contrary to our expectation, isotopic variation among plants at our two western Amazon sites (várzea and igapó) was comparable to the variation reported from composite samples collected from várzea forests along a 1,800-km stretch of the central Amazon River (Martinelli et al. 1991). At a regional scale, a longitudinal gradient of ${ }^{13} \mathrm{C}$ enrichment in foliar tissue of trees and understory plants occurs as a result of greater recycling of ${ }^{13} \mathrm{C}$-depleted biogenic $\mathrm{CO}_{2}$ in the western portion of the Amazon Basin. In general, tree leaves from the easternmost site are enriched as much as $3 \%$ and understory leaves as much as $4 \%$, with respect to leaves from the westernmost site (Martinelli et al. 1991). At a local scale, foliar $\delta^{13} \mathrm{C}$ values of half the species we sampled at a single forest site fell within a range of $3 \%$.

The variation in foliar $\delta^{13} \mathrm{C}$ among co-occurring species revealed in the present study is comparable to levels of interspecific within-site variation found in other terra firme forests in the Amazon Basin (e.g., 9 to 12\%o at four forest sites (see Figure 1 in Ometto et al. 2006), 8\% at a forest site in southern Amazonia (Martinelli et al. 1998)). One of the explanations for large within-site variation in $\delta^{13} \mathrm{C}$ is the "canopy effect" that causes leaves closer to the forest floor to have more ${ }^{13} \mathrm{C}$-depleted $\delta^{13} \mathrm{C}$ signatures relative to leaves in the upper canopy. Two hypotheses have been postulated to explain this pattern. One idea is that light availability influences $\mathrm{CO}_{2}$ concentration within leaf intercellular spaces (Farquhar et al. 1982), and the other proposes vertical stratification in the isotopic composition of forest $\mathrm{CO}_{2}$ (Medina \& Minchin 1980). Contrary to patterns described for terra firme forests, some of the lowest $\delta^{13} \mathrm{C}$ values in the two flooded forests we sampled $(<-33 \%$ ) came from tree leaves collected from the crown (Appendices 1 and 2). Martinelli et al. (1994) hypothesized that proximity to the river may promote better mixing of atmospheric and ${ }^{13} \mathrm{C}$-depleted biogenic $\mathrm{CO}_{2}$ that, in conjunction with better light penetration, may prevent the occurrence of a 
strong "canopy effect" in flooded forests. Since the samples analyzed in this study included partially submerged species growing at different heights (e.g., small and large trees, shrubs, and vines) and under different light conditions (e.g., inside the forest and along the edge), the variation depicted by these data sets are examples of the natural distribution of $\delta^{13} \mathrm{C}$ among woody plants at a single forest site. Larger sample sizes within each stratum would be needed to test for effects of plant height or distance from the river's edge.

The two flooded forest sites analyzed in this study also revealed significant variation in $\delta^{15} \mathrm{~N}$ among co-occurring species. Such ranges are similar to those reported for foliar $\delta^{15} \mathrm{~N}$ among non- $\mathrm{N}_{2}$-fixing woody plants in a várzea forest (ca. 5.5\%, Figure 2 in Kreibich et al. 2006) and a terra firme forest (5.5\%, Ometto et al. 2006) sampled during the dry season near Manaus in the central Amazon Basin. Wider ranges of variation in foliar $\delta^{15} \mathrm{~N}$ among non- $\mathrm{N}_{2}$-fixing woody plants have been reported in other tropical terra firme forests, including three sites within the Amazon Basin (7-8\%, Ometto et al. 2006).

Within-site variation in foliar $\delta^{15} \mathrm{~N}$ is partially explained by the presence of $\mathrm{N}_{2}$-fixing species. Although $\mathrm{N}_{2}$-fixers generally have $\delta^{15} \mathrm{~N}$ signatures slightly lower than that of atmospheric $\mathrm{N}_{2}$ (i.e., from -1 to $-2 \%$, Shearer \& Kohl 1991), non- $\mathrm{N}_{2}$-fixers also can have low $\delta^{15} \mathrm{~N}$ (e.g. Domenach et al. 1989, Roggy et al. 1999, Kreibich et al. 2006). Samples from the várzea of the Tarapoto Lakes complex did not include legume species, and only three legume species were sampled in the igapó of the lower Apaporis River. Foliar $\delta^{15} \mathrm{~N}$ of those three species, however, had values $>3 \%$ suggesting that these are most likely non- $\mathrm{N}_{2}$-fixers. Access to alternative $\mathrm{N}$ pools due to mycorrhizal associations and differential root depth can cause $\delta^{15} \mathrm{~N}$ variation among non- $\mathrm{N}_{2}$-fixing plants (Handley \& Raven 1992, Högberg 1997). In a várzea forest site near Manaus, Kreibich et al. (2006) found a non- $\mathrm{N}_{2}$-fixing tree species with high ectomycorrhizal density having lower $\delta^{15} \mathrm{~N}$ than co-occurring non- $\mathrm{N}_{2}$-fixing species without mycorrhiza. Roggy et al. (1999) found longer roots and more depleted $\delta^{15} \mathrm{~N}$ signatures among non- $\mathrm{N}_{2}$-fixing pioneer species compared with primary-forest species in a terra firme rainforest site in French Guiana. In flooded forests, root length can reach up to $30 \mathrm{~m}$ in some species (Worbes 1997), but the relationship between root length and foliar $\delta^{15} \mathrm{~N}$ remains to be examined in these forests.

\section{Within-plant isotopic variation}

As expected, wood and fruit had different isotopic signatures than paired leave samples. Generally, non-photosynthetic tissues in $\mathrm{C}_{3}$ plants are ${ }^{13} \mathrm{C}$-enriched relative to leaves (Cernusak et al. 2009). Paired wood and leaf samples of trees in a terra firme forest in the southwestern Amazon revealed variation in $\delta^{13} \mathrm{C}$ (range $=-0.85$ to $+9 \%$, $\mathrm{n}=33$ trees; Martinelli et al. 1998) larger than that observed in the várzea of the Tarapoto Lakes complex. Although the pattern of ${ }^{13} \mathrm{C}$ enrichment in wood relative to leaves appears to be widespread across diverse taxa and ecosystems, causal mechanisms remain poorly understood (Bowling et al. 2008), and a combination of processes likely contribute to this pattern (Cernusak et al. 2009).

Within-plant variation in $\delta^{15} \mathrm{~N}$ is usually $<3 \%$ between leaves and roots from plants in temperate deciduous forests and tallgrass prairies, while desert plants can have up to 7\%o individual variation (Evans 2001). Greater ${ }^{15} \mathrm{~N}$-enrichment of trunk wood (i.e., bark and sapwood) relative to leaves was apparent for most of the plant species analyzed in the Tarapoto Lakes várzea; however, this pattern may not be repeated in other ecosystems. For example, lower $\delta^{15} \mathrm{~N}$ values in trunk wood relative to those of leaves were found among a $\mathrm{N}_{2}$-fixing legume (Prosopis glandulosa) in the Sonora Desert (Shearer et al. 1983). Differential $\mathrm{N}$ values among tissues are the result of internal N cycling within plants (Shearer et al. 1983).

Our results regarding a generalized ${ }^{13} \mathrm{C}$ enrichment in fruit relative to leaves in a várzea forest represent a significant contribution to the little existing evidence for isotopic variation between fruits and leaves among woody plants. A recent study of mangrove forests revealed that fruits of most species had ${ }^{13} \mathrm{C}$-enriched signatures and lower $\mathrm{C}: \mathrm{N}$ ratios relative to leaves (Figure 3 and 7 in Muzuka \& Shunula 2006). Under experimental conditions, $\delta^{13} \mathrm{C}$ signatures seeds of an evergreen tree (Lithocarpus densiflorus) from the western United States, were less negative ( $>2 \%$ ) than leaves (Kennedy et al. 2004). Among herbaceous crops, $\delta^{13} \mathrm{C}$ signatures of chickpea pods and seeds were enriched by at least 3.1 and $4.7 \%$, respectively, relative to leaves under experimental conditions (Behboudian et al. 2000); and soybean pods were enriched by 1 to $2 \%$, relative to somatic tissues (Yoneyama et al. 2000). Varied enrichment in these herbaceous species and among várzea plants suggests that higher $\delta^{13} \mathrm{C}$ of fruits relative to leaves is species specific.

Mechanisms causing variation in $\delta^{13} \mathrm{C}$ of fruits and leaves within an individual plant remain poorly understood. Movement of compounds with differential isotopic composition inside the plant (Kennedy et al. 2004), respiratory differences among tissues, and recycling of $\mathrm{CO}_{2}$ inside the pod (Behboudian et al. 2000) are hypothesized as possible causes for the differences in $\delta^{13} \mathrm{C}$ between seeds and leaves. Fruit age also could influence isotopic variation, although, Handley and Scrimgeour (1997) found that $\delta^{13} \mathrm{C}$ of fruits from one shrub species increased as they matured, but for a different shrub species in the same field values declined by $3 \%$ during maturation. Sampling larger samples of fruits and leaves at multiple developmental stages and from a greater number of species would clarify these relationships.

Information concerning variation in $\delta{ }^{15} \mathrm{~N}$ of fruit and leaves is even more limited. Patterns of ${ }^{15} \mathrm{~N}$ enrichment in fruits relative to leaves are consistent across three dominant shrub species in a successional field in Scotland (Handley \& Scrimgeour 1997). In contrast to the patterns of enrichment in fruits observed among most várzea plants, fruits of $P$. glandulosa in the Sonora Desert had slightly lower $\delta^{15} \mathrm{~N}$ signatures than leaves (Shearer et al. 1983). Soybean pods also had lower $\delta^{15} \mathrm{~N}$ than vegetative parts (Yoneyama et al. 2000).

\section{Implications of plant isotopic variation for food-web research}

Requirements for multiple samples from species, individuals, and tissues will obviously be determined by the research question and spatiotemporal scale of the study. $\delta^{15} \mathrm{~N}$ of leaves in our igapó forest were enriched by an average of $2.8 \%$ with respect to leaves from the várzea site. Because $\delta^{15} \mathrm{~N}$ usually increases 2-4\%o per trophic level (Post 2002, Vanderklift \& Ponsard 2003, German \& Miles 2010), establishing a reliable 
baseline is essential for estimation of consumer trophic positions.

In addition to between-site differences in $\delta^{15} \mathrm{~N}$, our isotopic analysis from multiple species showed wide inter-specific variation in $\delta^{13} \mathrm{C}$ and $\delta^{15} \mathrm{~N}$ at a given location. Samples encompassing plant taxa with diverse physiological attributes (e.g., $\mathrm{N}_{2}$-fixers- and non- $\mathrm{N}_{2}$-fixers), growth forms, and microhabitats (e.g., understory, canopy, inside forest, and edge) are needed in order to characterize natural within-site isotopic variation. This is especially true in species-rich ecosystems, such as tropical forests. For example, including only $\mathrm{N}_{2}$-fixers or only non- $\mathrm{N}_{2}$-fixers could produce different mean $\delta^{15} \mathrm{~N}$ values for macrophytes at the base of the food web (e.g., Roggy et al. 1999, Kreibich et al. 2006). In our study, $\delta^{15} \mathrm{~N}$ showed significant between- and within-site variation, and therefore in situ data should be used to establish primary production baselines for local food webs.

Large within-site variation in both $\delta^{13} \mathrm{C}$ and $\delta^{15} \mathrm{~N}$ observed at both sites in this study also emphasizes the need to use mixing models that can account for isotopic variation in basal production sources suspected of supporting consumer biomass (e.g., MixSIR, Moore \& Semmens 2008). As expected, the results of a mixing model predicting the relative contribution of different food sources to a fruit-eating fish were largely influenced by isotopic variation. The mixing model that used mean sources values without variability failed to find feasible source contributions to Mylossoma duriventre at our várzea site. This is because the fish fell outside the mixing polygon connecting mean source values (Figure 5; Phillips \& Gregg 2003). The magnitude of variation for a particular source (e.g., none, $1 \mathrm{SD}, 2 \mathrm{SD})$ greatly influenced model results for this consumer. Stomach contents analysis revealed that fruit is the most important food for $M$. duriventre during the flood season (Appendix 1). Models that accounted for variability in both $\delta^{13} \mathrm{C}$ and $\delta^{15} \mathrm{~N}$ of fruit confirmed that fruit accounts for a large fraction of $M$. duriventre's diet. Fish frugivory in Amazonian flooded forest is facilitated by high fruit production as most plants have their fruiting phenology synchronized with the flood season (Parolin et al. 2004). When only mean isotopic ratios were included, the model predicted that $\mathrm{C}_{3}$ aquatic macrophytes had the greatest contribution; however, aquatic macrophytes were not found in stomachs. Aquatic macrophytes may contribute to fish diets during the dry season, particularly in white-water rivers where macrophytes are abundant. Fruits have heavier $\delta^{13} \mathrm{C}$ and $\delta^{15} \mathrm{~N}$ than leaves which allowed for fairly good estimates of contributions of these sources to consumer biomass.

\section{Conclusions}

Within-source isotopic variation increases uncertainty in mixing model results (Boecklen et al. 2011, Fry 2013), and understanding of this variation is pivotal for sampling protocols for food-web research. Here we demonstrated that mean $\delta^{15} \mathrm{~N}$ but not $\delta^{13} \mathrm{C}$ differ between riparian plants from várzea and igapó forests of the Amazon. Within-site interspecific variation in $\delta^{13} \mathrm{C}$ and $\delta^{15} \mathrm{~N}$ was large, and fruits had heavier $\delta^{13} \mathrm{C}$ and $\delta^{15} \mathrm{~N}$ than leaves of the same plant. Large between-site variation in $\delta^{15} \mathrm{~N}$ emphasizes the need for in-situ sampling in order to establish reliable baselines for local food webs. Large interspecific variation in both $\delta^{13} \mathrm{C}$ and $\delta^{15} \mathrm{~N}$ of forest plants influenced the outcome of MixSIR models predicting contribution of terrestrial food sources to an aquatic consumer in a local food web. Differences in isotopic signatures among tissues within plants increased the ability of MixSIR models to correctly identify the most important food source. Thus, local inter-specific and among-tissue isotopic variation should be considered in sampling of basal production sources and modelling their relative contribution to consumer biomass.

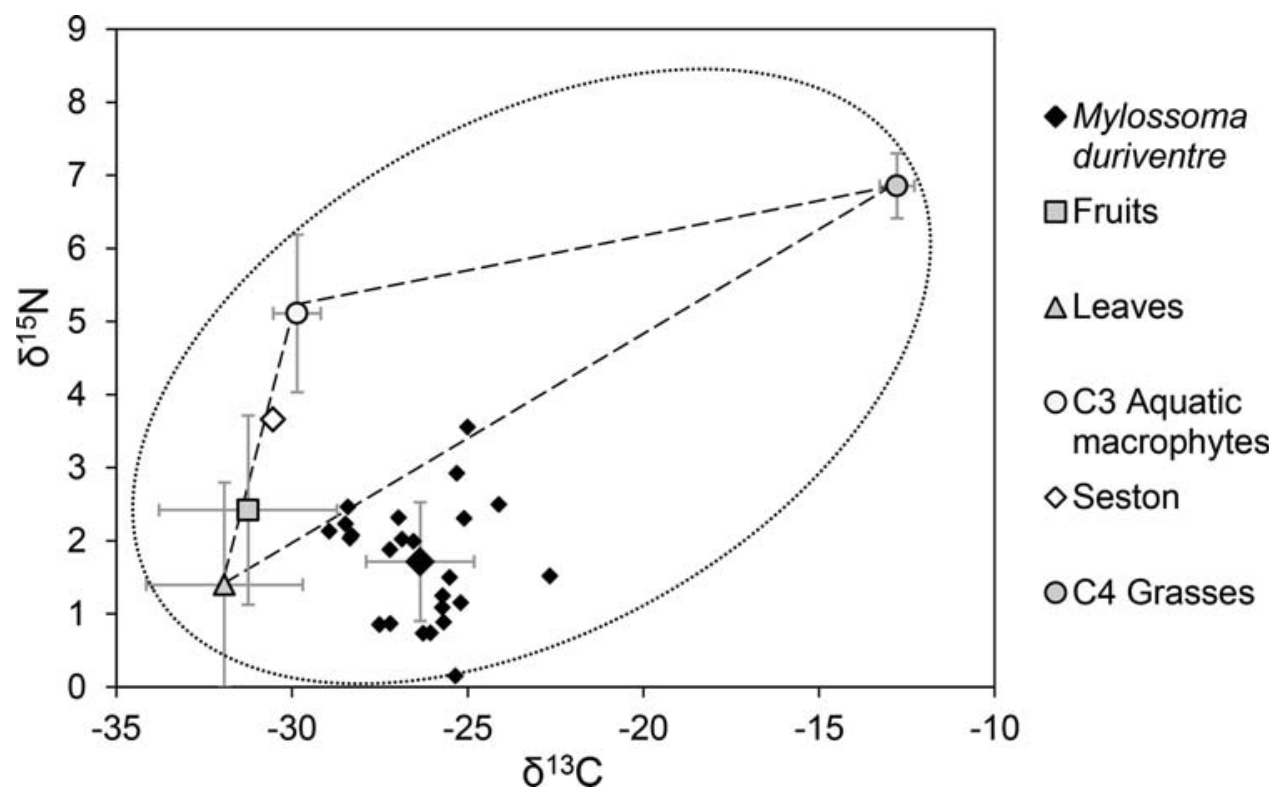

Figure 5. Carbon and nitrogen stable isotope ratios (mean $\pm \mathrm{SD}$ ) of a frugivorous fish and potential food sources (abundant primary producers) in the flooded forest (várzea) of the Tarapoto Lakes complex, western Amazonia. Small black diamonds represent isotopic signatures of individual fish. Fish positions were adjusted to account for trophic fractionation. Dashed polygon connects mean source values; dotted oval encloses sources within approximately one standard deviation of the mean. 


\section{Supplementary material}

Appendix 1. Diet of Mylossoma duriventre assessed from the volumetric analysis of stomach contents of 55 individuals caught during the rising waters season of 2007 in the flooded forest (várzea) of the Tarapoto Lakes complex, western Amazon Basin.

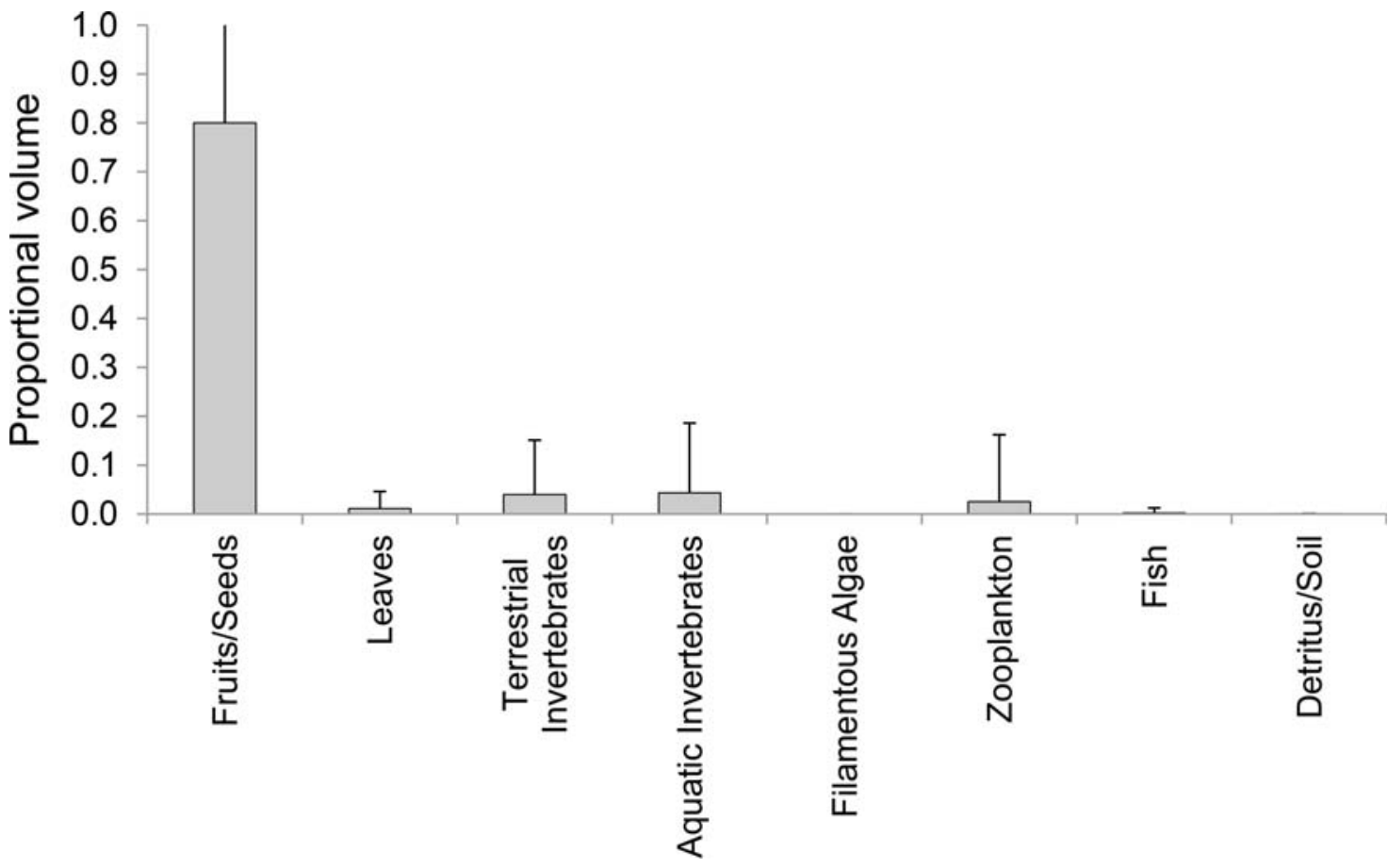

Appendix 2. Isotopic and elemental ratios of leaves and fruits of woody plants $(n=28$ and 22 species, respectively) in the flooded forest (várzea) of the Tarapoto Lakes complex, western Amazon Basin. Species: indet. = indeterminate. Growth habit: $\mathrm{Pl}=$ palm, $\mathrm{S}=$ shrub, $\mathrm{T}=$ tree, $\mathrm{Li}=$ liana. Tissue: $\mathrm{L}=$ leaf, $\mathrm{F}=$ fruit (pulp and seed $/ \mathrm{s}$ ), $\mathrm{S}=$ seed only, $\mathrm{P}=$ pulp only. Maturity: $\mathrm{M}=$ mature, $\mathrm{R}=$ ripe, $\mathrm{I}=$ immature. ${ }^{*}$ Species included in mixing models assessing the relative contribution of different food sources to a frugivorous fish.

\begin{tabular}{|c|c|c|c|c|c|c|c|c|}
\hline Family & Species & Code & $\begin{array}{c}\text { Growth } \\
\text { habit }\end{array}$ & Tissue & Maturity & $\delta^{13} \mathbf{C}$ & $\delta^{15} \mathbf{N}$ & $\begin{array}{c}\mathrm{C}: \mathbf{N} \\
\text { Ratio }\end{array}$ \\
\hline \multirow[t]{4}{*}{ Annonaceae } & Annonaceae indet. & Anin* & $\mathrm{T}$ & $\mathrm{L}$ & M & -29.52 & 1.64 & 27.46 \\
\hline & & & & $\mathrm{P}$ & I & -28.62 & 3.35 & 50.80 \\
\hline & Guatteria sp. & Gusp* & $\mathrm{T}$ & $\mathrm{L}$ & M & -32.97 & 0.46 & 24.90 \\
\hline & & & & $\mathrm{F}$ & I & -32.70 & 1.87 & 44.95 \\
\hline \multirow[t]{3}{*}{ Apocynaceae } & Tabernaemontana sp. & Tasp* & $\mathrm{S}$ & $\mathrm{L}$ & M & -29.73 & 1.16 & 18.37 \\
\hline & & & & $\mathrm{F}$ & I & -29.55 & 3.76 & 23.41 \\
\hline & Blepharodon sp. & Blsp & $\mathrm{Li}$ & $\mathrm{L}$ & M & -32.21 & 4.73 & 14.19 \\
\hline \multirow[t]{5}{*}{ Arecaceae } & Bactris sp.1 & Basp1* & $\mathrm{Pl}$ & $\mathrm{L}$ & M & -34.08 & 0.34 & 36.96 \\
\hline & & & & $\mathrm{S}$ & $\mathrm{n} / \mathrm{a}$ & -33.61 & 3.40 & 74.68 \\
\hline & Bactris sp. 2 & Basp2* & $\mathrm{Pl}$ & $\mathrm{L}$ & M & -33.90 & 0.85 & 28.64 \\
\hline & & & & $\mathrm{F}$ & $\mathrm{R}$ & -32.65 & 3.40 & 58.16 \\
\hline & Bactris sp. 3 & Basp3 & $\mathrm{Pl}$ & $\mathrm{F}$ & I & -30.76 & 1.60 & 44.30 \\
\hline Clusiaceae & Garcinia macrophylla & Gama & $\mathrm{T}$ & $\mathrm{L}$ & M & -30.57 & 1.21 & 31.17 \\
\hline \multirow[t]{3}{*}{ Euphorbiaceae } & Amanoa oblongifolia & Amob & $\mathrm{T}$ & $\mathrm{L}$ & M & -30.19 & -0.28 & 30.72 \\
\hline & Croton bilocularis & Crbi & $\mathrm{T}$ & $\mathrm{F}$ & I & -29.25 & 1.15 & 18.66 \\
\hline & Phyllanthus sp. & Physp & $\mathrm{S}$ & $\mathrm{L}$ & M & -32.64 & 1.21 & 22.59 \\
\hline \multirow[t]{2}{*}{ Hypericaceae } & Vismia macrophylla & Vima* & $\mathrm{T}$ & $\mathrm{L}$ & M & -32.96 & 1.04 & 33.59 \\
\hline & & & & $\mathrm{F}$ & $\mathrm{n} / \mathrm{a}$ & -35.33 & 2.68 & 28.56 \\
\hline
\end{tabular}


Appendix 2. Continued.

\begin{tabular}{|c|c|c|c|c|c|c|c|c|}
\hline Family & Species & Code & $\begin{array}{c}\text { Growth } \\
\text { habit }\end{array}$ & Tissue & Maturity & $\delta^{13} \mathbf{C}$ & $\delta^{15} \mathbf{N}$ & $\begin{array}{c}\text { C:N } \\
\text { Ratio }\end{array}$ \\
\hline \multirow[t]{3}{*}{ Melastomataceae } & Mouriri grandiflora & Mogr* & $\mathrm{T}$ & $\mathrm{L}$ & M & -34.31 & 2.47 & 30.63 \\
\hline & & & & $\mathrm{F}$ & $\mathrm{R}$ & -32.53 & 4.23 & 75.48 \\
\hline & Tococa guianensis & Togu & S & $\mathrm{L}$ & M & -31.47 & 2.71 & 24.52 \\
\hline \multirow[t]{2}{*}{ Myristicaceae } & Iryanthera $\mathrm{sp}$. & Irsp* & $\mathrm{T}$ & $\mathrm{L}$ & M & -33.47 & 0.82 & 27.78 \\
\hline & & & & $\mathrm{F}$ & $\mathrm{I}$ & -32.01 & 1.91 & 39.80 \\
\hline \multirow[t]{5}{*}{ Myrtaceae } & Myrtaceae indet. 1 & Myrt1 & $\mathrm{T}$ & $\mathrm{L}$ & M & -34.61 & 2.52 & 34.35 \\
\hline & Myrtaceae indet. 2 & Myrt2* & $\mathrm{T}$ & $\mathrm{L}$ & $\mathrm{M}$ & -35.41 & -0.33 & 34.69 \\
\hline & & & $\mathrm{T}$ & $\mathrm{F}$ & $\mathrm{R}$ & -32.62 & 1.13 & 41.10 \\
\hline & Myrtaceae indet. 3 & Myrt3* & $\mathrm{T}$ & $\mathrm{L}$ & M & -33.01 & 2.18 & 42.51 \\
\hline & & & & $\mathrm{F}$ & I & -31.06 & 2.68 & 46.04 \\
\hline \multirow[t]{2}{*}{ Ochnaceae } & Ouratea sp. & Ousp* & S & $\mathrm{L}$ & M & -27.03 & 3.32 & 36.02 \\
\hline & & & & $\mathrm{F}$ & $\mathrm{R}$ & -24.97 & 4.40 & 30.93 \\
\hline \multirow[t]{2}{*}{ Olacaceae } & Dulacia sp. & Dusp* & $\mathrm{T}$ & $\mathrm{L}$ & M & -33.69 & -0.11 & 32.21 \\
\hline & & & & $\mathrm{F}$ & $\mathrm{R}$ & -33.30 & 2.63 & 31.01 \\
\hline \multirow[t]{2}{*}{ Polygonaceae } & Symmeria paniculata & Sypa* & S & $\mathrm{L}$ & M & -29.84 & 2.56 & 36.45 \\
\hline & & & & $\mathrm{S}$ & $\mathrm{I}$ & -29.60 & 4.18 & 43.34 \\
\hline \multirow[t]{5}{*}{ Rubiaceae } & Alibertia sp. & Alsp & $\mathrm{T}$ & $\mathrm{L}$ & M & -32.12 & 4.65 & 15.98 \\
\hline & Faramea sp. & Fasp* & S & $\mathrm{L}$ & M & -33.21 & 2.88 & 26.70 \\
\hline & & & & $\mathrm{F}$ & I & -36.17 & 1.39 & 21.54 \\
\hline & Psychotria sp. & Pssp* & S & $\mathrm{L}$ & M & -30.89 & 4.21 & 15.00 \\
\hline & & & & $\mathrm{F}$ & $\mathrm{R}$ & -29.83 & 3.08 & 20.18 \\
\hline \multirow[t]{2}{*}{ Sapindaceae } & Paullinia sp. & Pasp* & $\mathrm{Li}$ & $\mathrm{L}$ & M & -32.07 & 0.19 & 33.89 \\
\hline & & & & $\mathrm{F}$ & I & -30.53 & 1.62 & 46.97 \\
\hline \multirow[t]{5}{*}{ Sapotaceae } & $\begin{array}{l}\text { Micropholis } \mathrm{cf} \text {. } \\
\text { venulosa }\end{array}$ & Micfve* & $\mathrm{T}$ & $\mathrm{L}$ & M & -31.39 & 1.42 & 38.85 \\
\hline & & & & $\mathrm{P}$ & I & -29.93 & 1.01 & 43.52 \\
\hline & Micropholis sp. & Misp & $\mathrm{T}$ & $\mathrm{L}$ & M & -35.22 & 1.24 & 27.23 \\
\hline & Pouteria sp. & Posp* & $\mathrm{T}$ & $\mathrm{L}$ & M & -32.82 & 0.67 & 29.62 \\
\hline & & & & $\mathrm{F}$ & I & -30.96 & 0.52 & 22.72 \\
\hline \multirow[t]{2}{*}{ Urticaceae } & Cecropia sp. & Cesp* & $\mathrm{T}$ & $\mathrm{L}$ & M & -28.70 & 1.44 & 18.23 \\
\hline & & & & $\mathrm{F}$ & I & -29.01 & 0.88 & 22.84 \\
\hline \multirow[t]{2}{*}{ Vitaceae } & Cissus sp. & Cisp* & $\mathrm{Li}$ & $\mathrm{L}$ & M & -29.48 & 0.75 & 15.63 \\
\hline & & & & $\mathrm{F}$ & I & -30.00 & 0.29 & 19.10 \\
\hline
\end{tabular}

Appendix 3. Isotopic and elemental ratios of leaves and fruits of woody plants ( $\mathrm{n}=10$ and 22 species, respectively) in the flooded forest (igapó) of the lower Apaporis River, western Amazon Basin. Values represent mean \pm SD. Species: indet. $=$ indeterminate. Growth habit: $\mathrm{H}=$ hemi- epiphyte, $\mathrm{Pl}=$ palm, $\mathrm{S}=$ shrub, $\mathrm{T}=$ tree, $\mathrm{Li}=$ liana. Tissue: $\mathrm{L}=$ leaf, $\mathrm{F}=$ fruit (pulp and seeds), $\mathrm{S}=$ seed only, $\mathrm{P}=$ pulp only. Maturity: $\mathrm{M}=$ mature, $\mathrm{Y}=$ young, $\mathrm{R}=$ ripe.

\begin{tabular}{|c|c|c|c|c|c|c|c|c|}
\hline Family & Species & $\begin{array}{c}\text { Growth } \\
\text { habit }\end{array}$ & Tissue & Maturity & $\delta^{13} \mathbf{C}$ & $\delta^{15} \mathbf{N}$ & C:N Ratio & $N$ \\
\hline \multirow[t]{2}{*}{ Apocynaceae } & Marsdenia rubrofusca & $\mathrm{Li}$ & $\mathrm{L}$ & $Y \& M$ & $-28.85 \pm 0.80$ & $4.76 \pm 0.48$ & $17.22 \pm 4.55$ & 4 \\
\hline & & & $\mathrm{S}$ & $\mathrm{R}$ & -26.97 & 5.35 & 18.29 & 1 \\
\hline Aquifoliaceae & Ilex $\mathrm{sp}$ & $\mathrm{S}$ & $\mathrm{F}$ & $\mathrm{R}$ & $-31.43 \pm 0.96$ & $4.29 \pm 0.39$ & $42.36 \pm 10.70$ & 5 \\
\hline \multirow[t]{2}{*}{ Arecaceae } & Bactris riparia & $\mathrm{Pl}$ & $\mathrm{P}$ & $\mathrm{R}$ & -32.83 & 5.62 & 47.70 & 1 \\
\hline & Astrocaryum jauari & $\mathrm{Pl}$ & $\mathrm{P}$ & $\mathrm{R}$ & $-29.57 \pm 0.28$ & $5.15 \pm 0.17$ & $33.89 \pm 2.02$ & 2 \\
\hline Chrysobalanaceae & Indet. & $\mathrm{T}$ & $\mathrm{L}$ & $\mathrm{Y}$ & -32.47 & 6.59 & 23.66 & 1 \\
\hline Ebenaceae & Diospyros poeppigiana & $\mathrm{T}$ & $\mathrm{S}$ & $\mathrm{n} / \mathrm{a}$ & -31.14 & 2.67 & 43.82 & 1 \\
\hline \multirow[t]{2}{*}{ Euphorbiaceae } & Alchornea discolor & $\mathrm{T}$ & $\mathrm{F}$ & $\mathrm{R}$ & -27.60 & 1.24 & 19.13 & 1 \\
\hline & Mabea nitida & $\mathrm{T}$ & $\mathrm{L}$ & M & -33.69 & 3.93 & 22.90 & 1 \\
\hline \multirow[t]{3}{*}{ Fabaceae } & Inga sp.1 & $\mathrm{T}$ & $\mathrm{L}$ & $\mathrm{Y}$ & $-30.14 \pm 0.16$ & $3.45 \pm 0.41$ & $15.12 \pm 1.24$ & 2 \\
\hline & & & $\mathrm{P}$ & $\mathrm{R}$ & $-30.45 \pm 1.14$ & $0.77 \pm 0.24$ & $22.43 \pm 1.96$ & 3 \\
\hline & Inga sp. 2 & $\mathrm{~T}$ & $\mathrm{~L}$ & $\mathrm{Y}$ & -31.60 & 3.41 & 12.53 & 1 \\
\hline
\end{tabular}


Appendix 3. Continued.

\begin{tabular}{|c|c|c|c|c|c|c|c|c|}
\hline Family & Species & $\begin{array}{c}\text { Growth } \\
\text { habit }\end{array}$ & Tissue & Maturity & $\delta^{13} \mathrm{C}$ & $\delta^{15} \mathbf{N}$ & C:N Ratio & $N$ \\
\hline & $\begin{array}{l}\text { Macrolobium } \\
\text { acaciifolium }\end{array}$ & $\mathrm{T}$ & $\mathrm{L}$ & $\mathrm{Y}$ & -28.61 & 5.83 & 13.72 & 1 \\
\hline & & & S & $\mathrm{R}$ & -27.89 & 4.02 & 29.21 & 1 \\
\hline & & & $\mathrm{F}$ & $\mathrm{R}$ & -30.52 & 4.26 & 34.80 & 1 \\
\hline \multirow[t]{2}{*}{ Lauraceae } & Nectandra egensis & $\mathrm{T}$ & $\mathrm{L}$ & M & $-30.86 \pm 0.57$ & $4.11 \pm 0.52$ & $26.66 \pm 3.37$ & 3 \\
\hline & & & $\mathrm{F}$ & $\mathrm{R}$ & $-29.78 \pm 1.11$ & $3.82 \pm 1.21$ & $65.67 \pm 23.03$ & 3 \\
\hline Malpighiaceae & Byrsonima japurensis & $\mathrm{T}$ & $\mathrm{F}$ & $\mathrm{R}$ & $-32.60 \pm 0.23$ & $3.97 \pm 0.91$ & 71.85 & 3 \\
\hline \multirow{2}{*}{ Melastomataceae } & Miconia splendens & $\mathrm{T}$ & $\mathrm{F}$ & $\mathrm{n} / \mathrm{a}$ & -29.38 & 4.14 & 33.01 & 1 \\
\hline & Tococa coronata & $\mathrm{S}$ & $\mathrm{F}$ & $\mathrm{R}$ & -30.54 & 6.35 & 24.09 & 1 \\
\hline \multirow[t]{2}{*}{ Moraceae } & Ficus americana & $\mathrm{H}$ & $\mathrm{L}$ & $Y \& M$ & $-32.46 \pm 0.23$ & $4.07 \pm 0.63$ & $24.48 \pm 3.43$ & 2 \\
\hline & & & $\mathrm{F}$ & $\mathrm{R}$ & $-31.86 \pm 0.87$ & $4.37 \pm 0.46$ & $47.63 \pm 7.18$ & 3 \\
\hline \multirow[t]{2}{*}{ Myrtaceae } & Eugenia sp. & $\mathrm{T}$ & $\mathrm{F}$ & $\mathrm{R}$ & -33.32 & 0.60 & 85.96 & 1 \\
\hline & Psidium densicomum & S & $\mathrm{L}$ & $Y \& M$ & $-29.07 \pm 1.98$ & $4.20 \pm 0.82$ & $17.60 \pm 5.01$ & 6 \\
\hline Ochnaceae & Quiina amazonica & $\mathrm{S}$ & $\mathrm{F}$ & $\mathrm{R}$ & -26.88 & 3.22 & 49.51 & 1 \\
\hline Polygonaceae & Symmeria paniculata & $\mathrm{S}$ & $\mathrm{L}$ & $\mathrm{Y}$ & $-28.57 \pm 1.26$ & $3.99 \pm 1.06$ & $17.69 \pm 2.17$ & 3 \\
\hline \multirow[t]{4}{*}{ Rubiaceae } & Psychotria cf. lupulina & $\mathrm{S}$ & $\mathrm{F}$ & $\mathrm{R}$ & $-31.46 \pm 1.67$ & $4.86 \pm 0.69$ & $23.86 \pm 4.97$ & 4 \\
\hline & Bothriospora corymbosa & S & $\mathrm{F}$ & $\mathrm{R}$ & $-29.51 \pm 0.76$ & $5.45 \pm 0.68$ & $22.24 \pm 1.14$ & 4 \\
\hline & Genipa americana & $\mathrm{T}$ & $\mathrm{F}$ & $\mathrm{R}$ & $-29.40 \pm 0.57$ & $3.59 \pm 4.27$ & $43.09 \pm 17.53$ & 2 \\
\hline & Amaioua guianensis & $\mathrm{T}$ & $\mathrm{F}$ & $\mathrm{R}$ & -32.18 & 3.41 & 78.12 & 1 \\
\hline Sapindaceae & Matayba guianensis & $\mathrm{T}$ & $\mathrm{F}$ & $\mathrm{R}$ & $-31.02 \pm 1.14$ & $3.72 \pm 1.08$ & $44.95 \pm 6.41$ & 4 \\
\hline Simaroubaceae & Simaba orinocensis & $\mathrm{T}$ & $\mathrm{P}$ & $\mathrm{R}$ & -27.68 & 5.46 & 15.76 & 1 \\
\hline
\end{tabular}

\section{Acknowledgements}

We thank Jed Macdonald, Gaby Támez, John Baker, Diomedes Silva, and Ciro for field assistance. Fernando Trujillo (Fundación Omacha), Sarita Kendall (Fundación Natütama), Santiago Duque (Universidad Nacional de Colombia, Sede Leticia), Francis and Edwin Palacios (Conservación Internacional), and Pablo Stevenson (Universidad de los Andes) provided crucial logistic support in Colombia. We thank indigenous leaders of the Resguardo Ticoya (Puerto Nariño) and Resguardo Yaigojé-Apaporis (Puerto Numi and Bocas de Taraira) for access to their territories. Research permits were granted by the Instituto Alexander von Humboldt and Instituto Colombiano de Agricultura, Colombia. Funding was provided by the Wildlife Conservation Society's Research Fellowship Program and the estate of Carolyn Wierichs Kelso. Idea Wild generously donated equipment used in this research. Steve Davis provided valuable comments on the manuscript.

\section{References}

AMUNDSON, R., AUSTIN, A.T., SCHUUR, E.A.G., YOO, K., MATZEK, V., KENDALL, C., UEBERSAX, A., BRENNER, D., \& BAISDEN, W.T. 2003. Global patterns of the isotopic composition of soil and plant nitrogen. Glob. Biogeochem. Cycles 17:1031.

ARAUJO-LIMA, C.A.R.M., FORSBERG, B., VICTORIA, R., \& MARTINELLI, L. 1986. Energy sources for detritivorous fishes in the Amazon. Science 234:1256-1258, http://dx.doi.org/10.1126/ science.234.4781.1256

ARRINGTON, D.A. \& WINEMILLER, K.O. 2002. Preservation effects on stable isotope analysis of fish muscle. Trans. Am. Fish. Soc. 131: 337-342, http://dx.doi.org/10.1577/1548-8659(2002)131<0337:PEOSIA $>2.0 . \mathrm{CO} ; 2$

BADECK, F.-W., TCHERKEZ, G., NOGUÉS, S., PIEL, C., \& GHASHGHAIE, J. 2005. Post-photosynthetic fractionation of stable carbon isotopes between plant organs -a widespread phenomenon. Rapid Commun. Mass Spectrom. 19:1381-1391, http://dx.doi.org/10.1002/rcm.1912

BARNETT, A.A., DE CASTILHO, C.V., SHAPLEY, R.L., \& ANICACIO, A. 2005. Diet, habitat selection and natural history of Cacajao melanocephalus ouakary in Jau National Park, Brazil. Int. J. Primatol. 26:949-969, http://dx.doi.org/10.1007/s10764-0055331-5

BEHBOUDIAN, M.H., MA, Q., TURNER, N.C., \& PALTA, J.A. 2000. Discrimination against ${ }^{13} \mathrm{CO}_{2}$ in leaves, pod walls, and seeds of water-stressed chickpea. Photosynthetica 38:155-157, http://dx.doi.org/10.1023/A:1026768513073

BENEDITO-CECILIO, E., ARAUJO-LIMA, C.A.R.M., FORSBERG, B.R., BITTENCOURT, M.M., \& MARTINELLI, L.C. 2000. Carbon sources of Amazonian fisheries. Fish. Manage. Ecol. 7:305-314, http://dx.doi.org/10.1046/j.1365-2400.2000.007004305.x

BOECKLEN, W., YARNES, C.T., BETHANY, A.C., \& AVIS, C.J. 2011. On the use of stable isotopes in trophic ecology. Annu. Rev. Ecol., Evol. Syst. 42:411-440, http://dx.doi.org/10.1146/annurev-ecolsys102209-144726

BOTERO, P., editor. 1999. Paisajes fisiográficos de la OrinoquíaAmazonía (ORAM) Colombia. Instituto Geográfico Agustín Codazzi, Bogotá, D.C.

BOWLING, D.R., PATAKI, D.E., \& RANDERSON, J.T. 2008. Carbon isotopes in terrestrial ecosystem pools and $\mathrm{CO}_{2}$ fluxes. New Phytol. 178:24 40, http://dx.doi.org/10.1111/j.1469-8137.2007. 02342.x

CAMPBELL, D.G., DALY, D.C., PRANCE, G.T., \& MACIEL, U.N. 1986. Quantitative ecological inventory of the terra firme and várzea tropical forest on the Rio Xingu, Brazilian Amazon. Brittonia 38:369-393, http://dx.doi.org/10.2307/2807085

CERNUSAK, L.A., TCHERKEZ, G., KEITEL, C., CORNWELL, W.K., SANTIAGO, L.S., KNOHL, A., BARBOUR, M.M., WILLIAMS, D.G., REICH, P.B., ELLSWORTH, D.S., DAWSON, T.E., GRIFFITHS, H.G., FARQUHAR, G.D., \& WRIGHT, I.J. 2009. Why are non-photosynthetic tissues generally ${ }^{13} \mathrm{C}$ enriched compared with leaves in $\mathrm{C}_{3}$ plants? Review and synthesis of current hypotheses. Funct. Plant Biol. 36:199-213, http://dx.doi.org/10.1071/FP08216 
CLAVIJO, L., BETANCUR, J., \& CÁRDENAS, D. 2009. Las plantas con flores de la Estación Biológica Mosiro Itajura-Caparú, Amazonía Colombiana. In Estación Biológica Mosiro-ItajuraCaparú. Biodiversidad en el Territorio del Yaigojé Apaporis. (ALARCÓN-NIETO, G. \& PALACIOS, E. eds). Conservación Internacional Colombia, Bogotá D.C., Colombia, Pages 55-97.

CORREA, S.B. 2003. Ichthyofauna of Lago Taraira, Lower Rio Apaporis sytem, Colombian Amazon. Dahlia 6:59-68.

CORREA, S.B. 2008. Fish assemblage structure is consistent through an annual hydrological cycle in habitats of a floodplainlake in the Colombian Amazon. Neotrop. Ichthyol. 6:257-266, http://dx.doi.org/10.1590/S1679-62252008000200014

CORREA, S.B. \& WINEMILLER, K.O. 2014. Niche partitioning among frugivorous fishes in response to fluctuating resources in the Amazonian floodplain forest. Ecology 95:210-224, http://dx.doi.org/10.1890/130393.1

DAWSON, T.E., MAMBELLI, S., PLAMBOECK, A.H., TEMPLER, P.H., \& TU, K.P. 2002. Stable isotopes in plant ecology. Annu. Rev. Ecol. Syst. 33:507-559, http://dx.doi.org/10.1146/annurev.ecolsys.33. 020602.095451

DEFLER, T.R. \& DEFLER, S.B. 1996. Diet of a group of Lagothrix lagothricha in southeastern Colombia. Int. J. Primatol. 17:161-190, http://dx.doi.org/10.1007/BF02735446

DENIRO, M.J. \& EPSTEIN, S. 1978. Influence of diet on the distribution of carbon isotopes in animals. Geochim. Cosmochim. Acta 42:495-506, http://dx.doi.org/10.1016/0016-7037(78)90199-0

DOMENACH, A., KURDALI, F., \& BARDIN, R. 1989. Estimation of symbiotic dinitrogen fixation in alder forest by the method based on natural ${ }^{15} \mathrm{~N}$ abundance. Plant Soil 118:51-59, http://dx.doi.org/10.1007/ BF02232790

DUQUE, S.R., PALACIOS, P., TRUJILlO, C., HUÉRFANO, A., \& LÓPEZ, S. 1997. Plan de manejo ambiental de los humedales localizados en el sistema de várzea comprendida en el interfluvio de los ríos Loretoyacu y Amazonas. Universidad Nacional de Colombia, Sede Amazonía. Corporación para el Desarrollo Sostenible del Sur de la Amazonía-Corpoamazonía, Leticia, Colombia.

EVANS, R.D. 2001. Physiological mechanisms influencing plant nitrogen isotope composition. Trends Plant Sci. 6:121-126, http://dx.doi.org/10.1016/S1360-1385(01)01889-1

FARQUHAR, G.D., O'LEARY, M.H., \& BERRY, J.A. 1982. On the relationship between carbon isotope discrimination and the intercellular carbon dioxide concentration in leaves. Aust. J. Plant Physiol. 9:121-137, http://dx.doi.org/10.1071/PP9820121

FORSBERG, B.R., ARAUJO-LIMA, C., MARTINELLI, L.A., VICTORIA, R.L., \& BONASSI, J.A. 1993. Autotrophic carbonsources for fish of the Central Amazon. Ecology 74:643-652, http://dx.doi.org/10.2307/1940793

FRY, B. 2006. Stable Isotope Ecology. Springer, New York., http://dx.doi.org/10.1007/0-387-33745-8

FRY, B. 2013. Alternative approaches for solving underdetermined isotope mixing problems. Mar. Ecol. Prog. Ser. 472:1-13, http://dx.doi.org/10.3354/meps10168

FRY, B. \& SHERR, E.B. 1984. $\mathrm{d}^{13} \mathrm{C}$ measurements as indicators of carbon flow in marine and freshwater ecosystems. Contrib. Mar. Sci. 27:13-47.

FURCH, K. 1997. Chemistry of várzea and igapó soils and nutrient inventory of their floodplain forests. In The central Amazon floodplain, ecology of a pulsing system. (JUNK, W. J. ed Springer-Verlag, Berlin, Pages 47-67, http://dx.doi.org/10.1007/978-3-662-03416-3

FYLLAS, N.M., PATINO, S., BAKER, T.R., BIELEFELD NARDOTO, G., MARTINELLI, L.A., QUESADA, C.A., PAIVA, R., SCHWARZ, M., HORNA, V., MERCADO, L.M., SANTOS, A., ARROYO, L., JIMÉNEZ, E.M., LUIZÃO, F.J., NEILL, D.A., SILVA, N., PRIETO, A., RUDAS, A., SILVIERA, M., VIEIRA, I.C.G., LOPEZ-GONZALEZ, G., MALHI, Y., PHILLIPS, O.L.., \& LLOYD, J. 2009. Basin-wide variations in foliar properties of Amazonian forest: phylogeny, soils and climate.
Biogeosciences 6:2677-2708, http://dx.doi.org/10.5194/bg-6-26772009

GERMAN, D. \& MILES, R. 2010. Stable carbon and nitrogen incorporation in blood and fin tissue of the catfish Pterygoplichthys disjunctivus (Siluriformes, Loricariidae). Environ. Biol. Fishes 89:117-133, http://dx.doi.org/10.1007/s10641-010-9703-0

GOULDING, M. 1980. The fishes and the forest: explorations in the Amazonian natural history. University of California Press, Berkeley.

HANDLEY, L.L., AUSTIN, A.T., ROBINSON, D., SCRIMGEOUR, C.M., RAVEN, J.A., HEATON, T.H.E., SCHMIDT, S., \& STEWART, G.R. 1999. The ${ }^{15} \mathrm{~N}$ natural abundance $\left(\delta^{15} \mathrm{~N}\right)$ of ecosystem samples reflects measures of water availability. Aust. J. Plant Physiol. 26:185-199, http://dx.doi.org/10.1071/PP98146

HANDLEY, L.L. \& RAVEN, J.A. 1992. The use of natural abundance of nitrogen isotopes in plant physiology and ecology. Plant, Cell Environ. 15:965-985, http://dx.doi.org/10.1111/j.1365-3040.1992.tb01650.x

HANDLEY, L.L. \& SCRIMGEOUR, C.M. 1997. Terrestrial plant ecology and ${ }^{15} \mathrm{~N}$ natural abundance: the present limits to interpretation of uncultivated systems with original data from a Scottish old field. Adv. Ecol. Res. 27:133-212, http://dx.doi.org/10.1016/ S0065-2504(08)60008-2

HASTON, E., RICHARDSON, J.E., STEVENS, P.F., CHASE, M.W., \& HARRIS, D.J. 2009. The Linear Angiosperm Phylogeny Group (LAPG) III: a linear sequence of the families in APG III. Bot. J. Linn. Soc. 161:128-131, http://dx.doi.org/10.1111/j.1095-8339.2009.01000.x

HAUGAASEN, T. \& PERES, C.A. 2006. Floristic, edaphic and structural characteristics of flooded and unflooded forests in the lower Rio Purús region of central Amazonia, Brazil. Acta Amazon. 36:25-35, http://dx.doi.org/10.1590/S0044-59672006000100005

HAUGAASEN, T. \& PERES, C.A. 2007. Vertebrate responses to fruit production in Amazonian flooded and unflooded forests. Conserv. Biol. 16:4165-4190, http://dx.doi.org/10.1007/s10531-007-9217-z

HAUGAASEN, T. \& PERES, C.A. 2008. Population abundance and biomass of large-bodied birds in Amazonian flooded and unflooded forests. Bird Conserv. Int. 18:87-101, http://dx.doi.org/10.1017/S0959 270908000130

HÖGBERG, P. 1997. Tansley review No. $95{ }^{15} \mathrm{~N}$ natural abundance in soilplant systems. New Phytol. 137:179-203, http://dx.doi.org/10.1046/j.14698137.1997.00808.x

HOORN, C. 2006. Mangrove forests and marine incursions in Neogene Amazonia (Lower Apaporis River, Colombia). Palaios 21:197-209, http://dx.doi.org/10.2110/palo.2005.p05-131

HOTHORN, T., HORNIK, K., VAN DE WIEL, M.A., \& ZEILEIS, A. 2008. Implementing a class of permutation tests: The coin package. Journal of Statistical Software 28:1-23, http://dx.doi.org/10.18637/jss. v028.i08

JORDANO, P. 2000. Fruits and frugivory. In Seeds: The Ecology of Regeneration in Plant Communities. 2nd edition. (FENNER, M. ed CABI International, Wallingford, UK, Pages 125-166, http://dx.doi.org/10.1079/9780851994321.0000

JUNK, W.J. \& PIEDADE, M.T.F. 2010. An introduction to South American wetland forests: distribution, definitions and general characterization. In Central Amazonian Floodplain Forests: Ecophysiology, Biodiversity, and Sustainable Management. (JUNK, W. J., PIEDADE, M. T. F., WITTMANN, F., SCHÖNGART, J., \& PAROLIN, P. eds). Springer, New York, Pages 4-25.

JUNK, W.J., SOARES, M.G.M., \& SAINT-PAUL, U. 1997. Structure and function of the large central Amazonian river floodplains: synthesis and discussion. In The central Amazon floodplain, ecology of a pulsing system. (JUNK, W. J. ed Springer-Verlag, Berlin, Pages 455-472, http://dx.doi.org/10.1007/978-3-662-03416-3

KENNEDY, P.G., HAUSMANN, N.J., WENK, E.H., \& DAWSON, T.E. 2004. The importance of seed reserves for seedling performance: an integrated approach using morphological, physiological, and stable isotope techniques. Oecologia 141:547-554, http://dx.doi.org/10.1007/s00442-004-1686-0 
KREIBICH, H., KERN, J., DE CAMARGO, P.B., MOREIRA, M.Z., VICTORIA, R.L., \& WERNER, D. 2006. Estimation of symbiotic $\mathrm{N}_{2}$ fixation in an Amazon floodplain forest. Oecologia 147:359-368, http://dx.doi.org/10.1007/s00442-005-0291-1

LAYMAN, C.A., ARAUJO, M.S., BOUCEK, R., HAMMERSCHLAG-PEYER, C.M., HARRISON, E., JUD, Z.R., MATICH, P., ROSENBLATT, A.E., VAUDO, J.J., YEAGER, L.A., POST, D.M., \& BEARHOP, S. 2012. Applying stable isotopes to examine food-web structure: an overview of analytical tools. Biol. Rev. 87:545-562, http://dx.doi.org/10.1111/j.1469-185X.2011.00208.x

MARTINELLI, L., DEVOL, A.H., VICTORIA, R., \& RICHEY, J.E. 1991. Stable carbon isotope variation in $C_{3}$ and $C_{4}$ plants along the Amazon River. Nature 353:57-59, http://dx.doi.org/10.1038/353057a0

MARTINELLI, L.A., ALMEIDA, S., BROWN, I.F., MOREIRA, M.Z., VICTORIA, R.L., STERNBERG, L.S.L., FERREIRA, C.A.C., \& THOMAS, W.W. 1998. Stable carbon isotope ratio of tree leaves, boles and fine litter in a tropical forest in Rondonia, Brazil. Oecologia 114:170-179, http://dx.doi.org/10.1007/s004420050433

MARTINELLI, L.A., PICCOLO, M.C., TOWNSEND, A.R., VITOUSEK, P.M., CUEVAS, E., MCDOWELL, W., ROBERTSON, G.P., SANTOS, O.C., \& TRESEDER, K. 1999. Nitrogen stable isotopic composition of leaves and soil: tropical versus temperate forests. Biogeochemistry 46:45-65, http://dx.doi.org/10.1007/978-94-011-4645-6_3

MARTINELLI, L.A., VICTORIA, R.L., FORSBERG, B.R., \& RICHEY, J.E. 1994. Isotopic composition of major carbon reservoirs in the Amazon floodplain. Int. J. Ecol. Environ. Sci. 20:31-46.

MARTINELLI, L.A., VICTORIA, R.L., TRIVELIN, P.C.O., DEVOI, A.H., \& RICHEY, J.E. $1992 .{ }^{15} \mathrm{~N}$ abundance in plants of the Amazon River floodplain and potential atmospheric $\mathrm{N}_{2}$ fixation. Oecologia 90:591-596, http://dx.doi.org/10.1007/BF01875455

MCCUTCHAN, J.H., LEWIS, W.M., KENDALL, C., \& MCGRATH, C.C. 2003. Variation in trophic shift for stable isotope ratios of carbon, nitrogen, and sulfur. Oikos 102:378-390, http://dx.doi.org/10.1034/j.1600-0706.2003.12098.x

MEDINA, E. \& MINCHIN, P. 1980. Stratification of $\delta^{13} \mathrm{C}$ values of leaves in Amazonian rain forests. Oecologia 45:377-378, http://dx.doi.org/10.1007/BF00540209

MOORE, J.W. \& SEMMENS, B.X. 2008. Incorporating uncertainty and prior information into stable isotope mixing models. Ecol. Lett. 11:470-480, http://dx.doi.org/10.1111/j.1461-0248.2008.01163.x

MUZUKA, A.N.N. \& SHUNULA, J.P. 2006. Stable isotope compositions of organic carbon and nitrogen of two mangrove stands along the Tanzanian coastal zone. Estuar. Coast. Shelf Sci. 66:447-458, http://dx.doi.org/10.1016/j.ecss.2005.10.007

OLIVEIRA, A.C.B., MARTINELLI, L.A., MOREIRA, M.Z., SOARES, M.G.M., \& CYRINO, J.E.P. 2006. a. Seasonality of energy sources of Colossoma macropomum in a floodplain lake in the Amazon-lake Camaleao, Amazonas, Brazil. Fish. Manage. Ecol. 13:135-142, http://dx.doi.org/10.1111/j.1365-2400.2006.00481.x

OLIVEIRA, A.C.B., SOARES, M.G.M., MARTINELLI, L.A., \& MOREIRA, M.Z. 2006b. Carbon sources of fish in an Amazonian floodplain lake. Aquat. Sci. 68:229-238, http://dx.doi.org/10.1007/s000 27-006-0808-7

OMETTO, J.P.H.B., EHLERINGER, J.R., DOMINGUES, T.F., BERRY, J.A., ISHIDA, F.Y., MAZZI, E., HIGUCHI, N.,
FLANAGAN, L.B., NARDOTO, G.B., \& MARTINELLI, L.A. 2006. The stable carbon and nitrogen isotopic composition of vegetation in tropical forests of the Amazon Basin, Brazil. Biogeochemistry 79:251-274, http://dx.doi.org/10.1007/s10533-006-9008-8

PAROLIN, P., DE SIMONE, O., HAASE, K., WALDHOFF, D., ROTTENBERGER, S., KUHN, U., KESSELMEIER, J., KLEISS, B., SCHMIDT, W., PIEDADE, M.T.F., \& JUNK, W.J. 2004. Central Amazonian floodplain forests: tree adaptations in a pulsing system. Bot. Rev. 70:357-380, http://dx.doi.org/10.1663/ 0006-8101(2004)070[0357:CAFFTA]2.0.CO;2

PETERSON, B.J. \& FRY, B. 1987. Stable isotopes in ecosystem studies. Annu. Rev. Ecol. Syst. 18:293-320, http://dx.doi.org/10.1146/ annurev.es.18.110187.001453

PHILLIPS, D.L. \& GREGG, J.W. 2003. Source partitioning using stable isotopes: coping with too many sources. Oecologia 136: 261-269, http://dx.doi.org/10.1007/s00442-003-1218-3

POST, D.M. 2002. Using stable isotopes to estimate trophic position: Models, methods, and assumptions. Ecology 83:703-718, http://dx.doi.org/10.1890/0012-9658(2002)083[0703:USITET]2.0.CO;2

R-CORE-DEVELOPMENT-TEAM. 2012. R: A language and environment for statistical computing. R Foundation for Statistical Computing, Viena, Austria.

ROGGY, J.C., PRÉVOST, M.F., GOURBIERE, F., CASABIANCA, H., GARBAYE, J., \& DOMENACH, A.M. 1999. Leaf natural ${ }^{15} \mathrm{~N}$ abundance and total $\mathrm{N}$ concentration as potential indicators of plant $\mathrm{N}$ nutrition in legumes and pioneer species in a rain forest of French Guiana. Oecologia 120:171-182, http://dx.doi.org/10.1007/ s004420050846

SHEARER, G. \& KOHL, D. 1991. The ${ }^{15} \mathrm{~N}$ natural abundance method for measuring biological nitrogen fixation: practicalities and possibilities. In Stable isotopes in plant nutrition, soil fertility and environmental studies. (FLITTON, S. P. ed International Atomic Energy Association, Vienna, Pages 103-115.

SHEARER, G., KOHL, D.H., VIRGINIA, R.A., BRYAN, B.A., SKEETERS, J.L., NILSEN, E.T., SHARIFI, M.R., \& RUNDEL, P.W. 1983. Estimates of $\mathrm{N}_{2}$-fixation from variation in the natural abundance of ${ }^{15} \mathrm{~N}$ in Sonoran desert ecosystems. Oecologia 56:365-373, http://dx.doi.org/10.1007/BF00379714

SIOLI, H. 1984. The Amazon and its main affluents: Hydrography, morphology of the river courses, and river types. In The Amazon. Limnology and landscape ecology of a mighty tropical river and its basin. (SIOLI, H. ed Dr. W. Junk, Dordrecht, The Netherlands., Pages 127-165, http://dx.doi.org/10.1007/978-94-009-6542-3_5

VANDERKLIFT, M.A. \& PONSARD, S. 2003. Sources of variation in consumer-diet $\delta^{15} \mathrm{~N}$ enrichment: a meta-analysis. Oecologia 136:169-182, http://dx.doi.org/10.1007/s00442-003-1270-z

WEST, J.B., BOWEN, G.J., CERLING, T.E., \& EHLERINGER, J.R. 2006. Stable isotopes as one of nature's ecological recorders. Trends Ecol. Evol. 21:408-414, http://dx.doi.org/10.1016/j.tree.2006.04.002

WORBES, M. 1997. The forest ecosystem of the floodplains. In The central Amazon floodplain, ecology of a pulsing system. (JUNK, W. J. ed Springer, Berlin, Pages 223-260.

YONEYAMA, T., FUJIWARA, H., \& ENGELAAR, W. 2000. Weather and nodule mediated variations in $\delta^{13} \mathrm{C}$ and $\delta^{15} \mathrm{~N}$ values in field-grown soybean (Glycine max L.) with special interest in the analyses of xylem fluids. J. Exp. Bot. 51:559-566, http://dx.doi.org/10.1093/jexbot/ 51.344 .559 